\title{
Six new species and eight new records of Gesneriaceae from Laos
}

\author{
K. Souvannakhoummane ${ }^{1 *}$, S. Lanorsavanh ${ }^{1}$, S. Tagane ${ }^{2}$, P. Souladeth ${ }^{3}$, \\ P. Phonepaseuth ${ }^{4}$, W. Pongamornkul ${ }^{5} \&$ V. Lamxay ${ }^{1}$ \\ ${ }^{1}$ Faculty of Natural Science, National University of Laos, \\ Dongdok Campus, Xaythany District, Vientiane Capital, Laos \\ "keooudone1988@gmail.com \\ ${ }^{2}$ Kagoshima University Museum, 1-21-30, Korimoto, Kagoshima, 890-0065, Japan \\ ${ }^{3}$ Faculty of Forest Science, National University of Laos, Dongdok Campus, \\ Xaythany District, Vientiane Capital, Laos \\ ${ }^{4}$ Faculty of Environmental Science, National University of Laos, Dongdok Campus, \\ Xaythany District, Vientiane Capital, Laos \\ ${ }^{5}$ Queen Sirikit Botanic Garden, The Botanical Garden Organization, \\ Chiang Mai 50180, Thailand
}

\begin{abstract}
Six new species of Gesneriaceae from Laos, namely Didymocarpus angustiflorus Souvann. \& Lanors., D. bolavenensis Souvann., Soulad. \& Phonep., D. laoticus Souvann. \& Lanors., D. trilobus Souvann. \& Phonep., Hemiboea olivifolia Souvann. \& Tagane and Paraboea planiflora Souvann. \& Lanors., are described and illustrated. Additionally, Aeschynanthus bracteatus Wall. ex A.DC., A. micranthus C.B.Clarke, Epithema ceylanicum Gardner, Lysionotus serratus D.Don, Microchirita luteola C.Puglisi, Paraboea swinhoei (Hance) B.L.Burtt, Petrocosmea kerrii Craib and Pseudochirita guangxiensis (S.Z.Huang) W.T.Wang, are newly recorded for the flora of Laos.
\end{abstract}

Keywords. Didymocarpus, flora of Laos, Hemiboea, new distribution, new taxon, Paraboea, taxonomy

\section{Introduction}

The Gesneriaceae is a family mainly of herbs, more rarely shrubs, belonging to the order Lamiales. There are about 150 genera with more than 3700 species which are widely distributed in the tropics and subtropics of the Old and the New Worlds (Weber et al., 2020), more rarely extending to warm temperate regions. In Laos, 18 genera and 35 species are recognised in the recent checklist by the Royal Botanic Garden Edinburgh (continuously updated). Apart from this checklist, there are very few taxonomic publications on the plant diversity of Laos compared with neighbouring countries, in part because Laos is the country with the lowest density of herbarium collections in Southeast Asia (Newman et al., 2007; Middleton et al., 2019). Given the large number of Gesneriaceae taxa known to have narrowly endemic distributions in the wider region, with the consequence that they are less likely to be found and collected, more new national records and new taxa for Laos could be expected. 
Middleton et al. (2019) estimated that around 30 to 100 species of Gesneriaceae are yet to be discovered and described from Cambodia, Laos and Vietnam. Indeed, recent intensive floristic inventories and subsequent taxonomic studies on Gesneriaceae have already resulted in the description of a few new taxa for the flora of Laos, such as Chayamaritia banksiae D.J.Middleton (Middleton et al., 2015), Didymocarpus middletonii Souvann., Soulad. \& Tagane (Souvannakhoummane et al., 2019), D. albiflorus Souvann. \& Phonep. (Souvannakhoumane \& Phonepaseuth, 2020) and Paraboea khotamiae Phonep. \& Souvann. (Phonepaseuth et al. 2021). Additionally, Didymocarpus formosus Nangngam \& D.J.Middleton, Damrongia trisepala (Barnett) D.J.Middleton \& A. Weber and Middletonia reticulata (Barnett) C.Puglisi were recently recorded for the first time for Laos (Panyadee et al., 2020; Phonepaseuth et al. 2021).

In this paper, we describe six new species in three genera, Didymocarpus Wall., Hemiboea C.B.Clarke and Paraboea (C.B.Clarke) Ridl., based on recent field surveys as well as herbarium work at FOF, HNL, KAG, QBG, Biology-National University of Laos and investigations on living collections at the Pha Tad Ke Botanical Garden. We also report eight new distribution records in six genera, viz. Aeschynanthus Jack, Epithema Blume, Lysionotus D.Don, Microchirita (C.B.Clarke) Yin Z.Wang, Paraboea (C.B.Clarke) Ridl. and Pseudochirita W.T.Wang, for the flora of Laos.

\section{Materials and methods}

The materials available for this study were collected during fieldwork in the Pha Nam Yard Forest Reserve Area, Phou Souang Forest Reserve Area, Pha Yoak Forest Reserve Area, Phou Bia Mountain, Phou Chom Voy Provincial Protected Area, Phou Pha Marn Limestone Forest Reserve Area, Bolaven Plateau [partly belonging to Dong Houa Sao National Protected Area], and the Phou Khao Khouay National Protected Area (Fig. 1). Voucher specimens, including herbarium specimens and collections in alcohol, are deposited mainly in the herbaria of the Department of Biology of the National University of Laos, FOF and HNL, and partly at KAG, KKU and QBG. We also collected living plants to observe their flowers and fruits. These living collections were transplanted from the forest to the Pha Tad Ke Botanical Garden in Louangphabang. To identify the taxa and to ascertain the status of the new species, we consulted the taxonomic literature on Gesneriaceae in the region, including for example from India, Myanmar, China, Thailand and Vietnam (Wang, 1983; Xu \& Burtt, 1991; Hilliard \& Burtt, 1995; Wang et al., 1998; Middleton, 2007, 2009, 2018; Xu et al., 2008; Triboun \& Middleton, 2012; Nangngam \& Maxwell, 2013; Triboun, 2013; Nangngam \& Middleton, 2014; Phuong et al., 2014; Middleton et al., 2015; Puglisi et al., 2015, 2016; Möller et al., 2017; Puglisi \& Middleton, 2017a,b; Averyanov et al., 2020; Prasanna et al., 2020; Tran et al., 2020; Zhang et al., 2020; Do et al., 2021), and followed the keys to the infrafamilial taxa and genera of Gesneriaceae (Weber et al., 2020). Furthermore, the original protologues available on the Biodiversity Heritage Library website (http://biodiversitylibrary.org/) and the digitised specimen images available at AAU, BM, E, GXMI, K, KUN, LE, NY, P and PE were examined. 


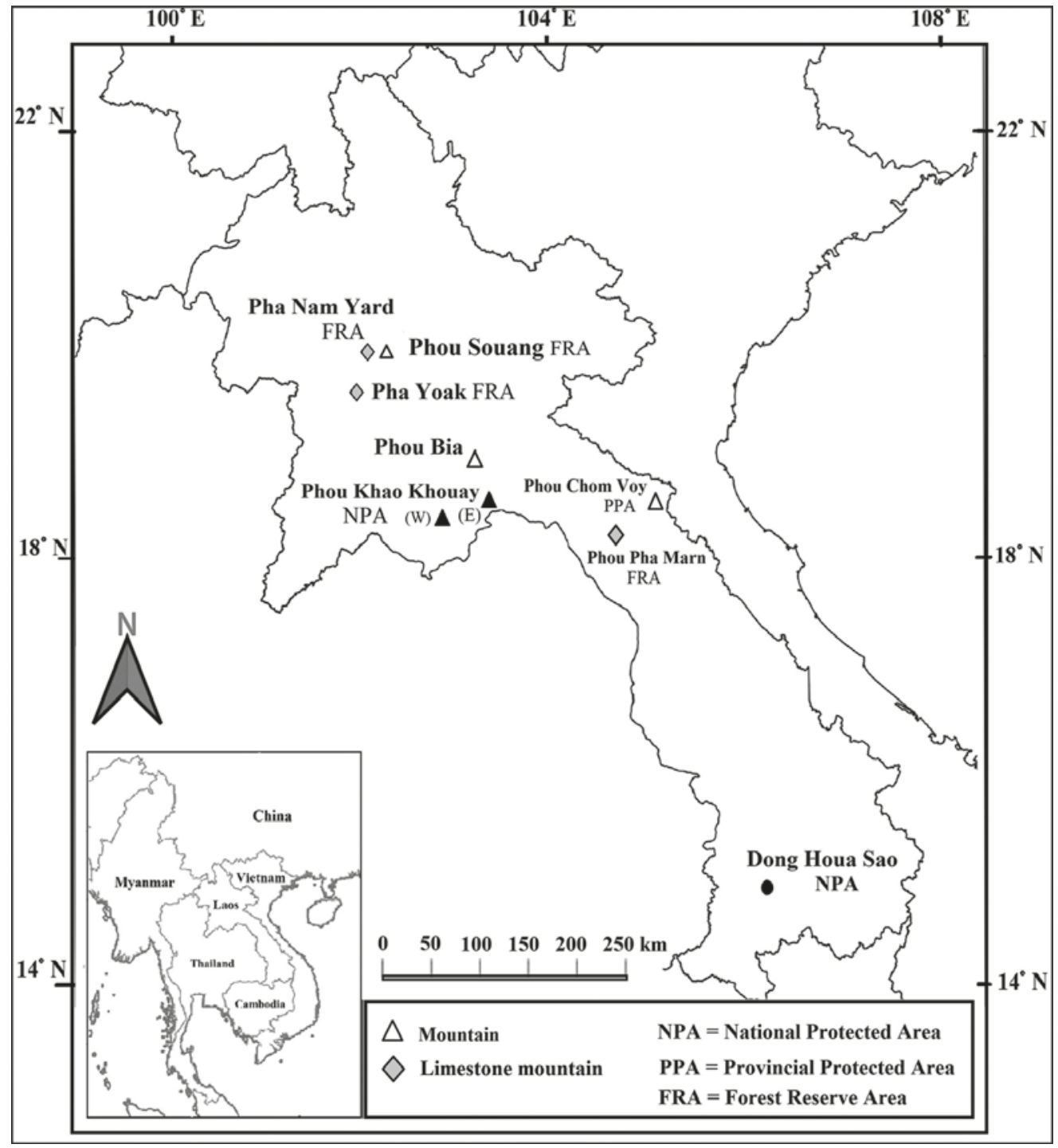

Fig. 1. Locations of the collection sites in this study: Pha Nam Yard Forest Reserve Area (FRA), Phou Souang FRA, Pha Yoak FRA, Phou Bia Mountain, Phou Chom Voy Provincial Protected Area, Phou Pha Marn Limestone FRA, Bolaven Plateau (partly belongs to Dong Houa Sao National Protected Area (NPA)), and Phou Khao Khouay NPA.

All specimens have been seen by the authors unless otherwise indicated; specimens examined via digital images are indicated with an asterisk $(*)$. The measurements were taken primarily from dried specimens and partly from collections in alcohol for floral characters. The illustrations were drawn from collections in alcohol, herbarium specimens and living plants. Photographs were taken and information on the habitat and ecology were noted when the specimens were collected in the field. A provisional IUCN conservation assessment is made for each species following the methodology of the IUCN Standards and Petitions Committee (2019). 


\section{Taxonomic treatment}

\section{Didymocarpus angustiflorus Souvann. \& Lanors., sp. nov.}

Morphologically similar to Didymocarpus payapensis Nangngam \& J.F.Maxwell from Thailand, in habit, elliptic lamina, and glabrous and salverform corolla, but differs in having lamina abaxially puberulent (vs glabrous), calyx 5-parted to base, green, with glands outside (vs calyx lobes divided c. 2/3 to the base, maroon, sparsely covered with multicellular glandular hairs and scattered pigment glands), corolla 1.5$2.2 \mathrm{~cm}$ long, dark blue with white patch in mouth (vs c. $2.5 \mathrm{~cm}$ long, dark purple), filaments sparsely multicellular glandular puberulent (vs glabrous), and style glabrous (vs sparsely covered with multicellular glandular hairs). - TYPE: Laos, Bolikhamxai Province, Thaphabath District, Phou Khao Khouay National Protected Area, 1032 m, $18^{\circ} 29^{\prime} 37.7^{\prime \prime} \mathrm{N} 103^{\circ} 17^{\prime} 49.0^{\prime \prime} \mathrm{E}, 29$ August 2020, Lanorsavanh, Souvannakhoummane \& Yhuangyayear SL 1975 (holotype HNL; isotypes FOF, KKU). (Fig. 2, 4A-C)

Deciduous, epilithic, perennial herbs, $25-35 \mathrm{~cm}$ tall including inflorescences. Stems 2-4 $\mathrm{mm}$ in diam., erect, pale greenish to brown basally, tinged reddish towards apex, densely white puberulent; 2-4 longitudinal grooves on stems in dry specimens. Leaves opposite, decussate, crowded at the top of stem, anisophyllous in a pair; petioles 7-8 cm long, pale green to reddish brown, puberulent; lamina chartaceous, ovate-elliptic, 4-11.5 × 2-8 cm, apex acute, base slightly asymmetrically oblique, subcordate to cuneate, margin serrate, adaxially dark green, abaxially pale green, both surfaces puberulent; venation pinnate, with 4-6 pairs of secondary veins, prominent abaxially. Inflorescences arising from the axils of leaves on upper stem, cymose, (10-)25-54-flowered; peduncle erect, slender, 15-25 cm long, 0.6-1.1 mm in diam., reddish brown to green, densely puberulent, sparsely multicellular glandular puberulent; bracts paired, ovate-elliptic, $2-3 \times 1-1.5 \mathrm{~mm}$, apex rounded to acute, margin entire, pale green, puberulent; pedicel 4-7 $\mathrm{mm}$ long, 0.5-0.6 $\mathrm{mm}$ in diam., reddish green, multicellular glandular puberulent. Calyx 5-parted to base, green, with glands outside; lobes equal, linear, 2-3.5 $\times 0.3-0.6 \mathrm{~mm}$, apex acute to rounded. Corolla salverform, 1.5-2.2 cm long, glabrous, pale blue near base, dark blue distally with white patch in mouth; tube 1.2-1.9 cm long, 2-3 mm in diam.; limb distinctly 2-lipped, adaxial lip 2-lobed, lobes broadly reniform, 1.5-2 $\times 2.5-3.5 \mathrm{~mm}$, apex rounded, abaxial lip 3-lobed, lobes semi-orbicular, 3-4 × 2.8-3.8 mm, apex rounded. Fertile stamens 2, inserted 1-1.5 cm above base of corolla; filaments 5-6 mm long, slender, white, sparsely multicellular glandular puberulent; anthers coherent by their adaxial surfaces, brownish, ellipsoidal, $2.5-3 \times 1.4-1.6 \mathrm{~mm}$, tip and base rounded, sparsely whitebearded to glabrous; staminodes 3, filiform, inserted $2.2-2.7 \mathrm{~mm}$ below the stamens, white, glabrous, 2 lateral staminodes 1.2-1.4 mm long, apex thick capitate, central one smaller c. $0.5 \mathrm{~mm}$ long, apex capitate. Disc cylindrical, c. $2 \mathrm{~mm}$ high, white, glabrous, margin slightly undulate. Pistil 15-18 mm long; ovary cylindrical, 12-15 $\mathrm{mm}$ long, 0.6-1.2 mm in diam., pale green tinged, white towards the base, glabrous; style c. $3 \mathrm{~mm}$ long, c. $0.3 \mathrm{~mm}$ in diam., greenish, glabrous; stigma capitate, c. $1 \times 1$ $\mathrm{mm}$, concave at apex, greenish, glabrous. Capsule straight, narrowly cylindrical, 22$25 \mathrm{~mm}$ long, 1.5-2 $\mathrm{mm}$ in diam., glabrous, turning brown, longitudinally dehiscent. Seeds unknown. 


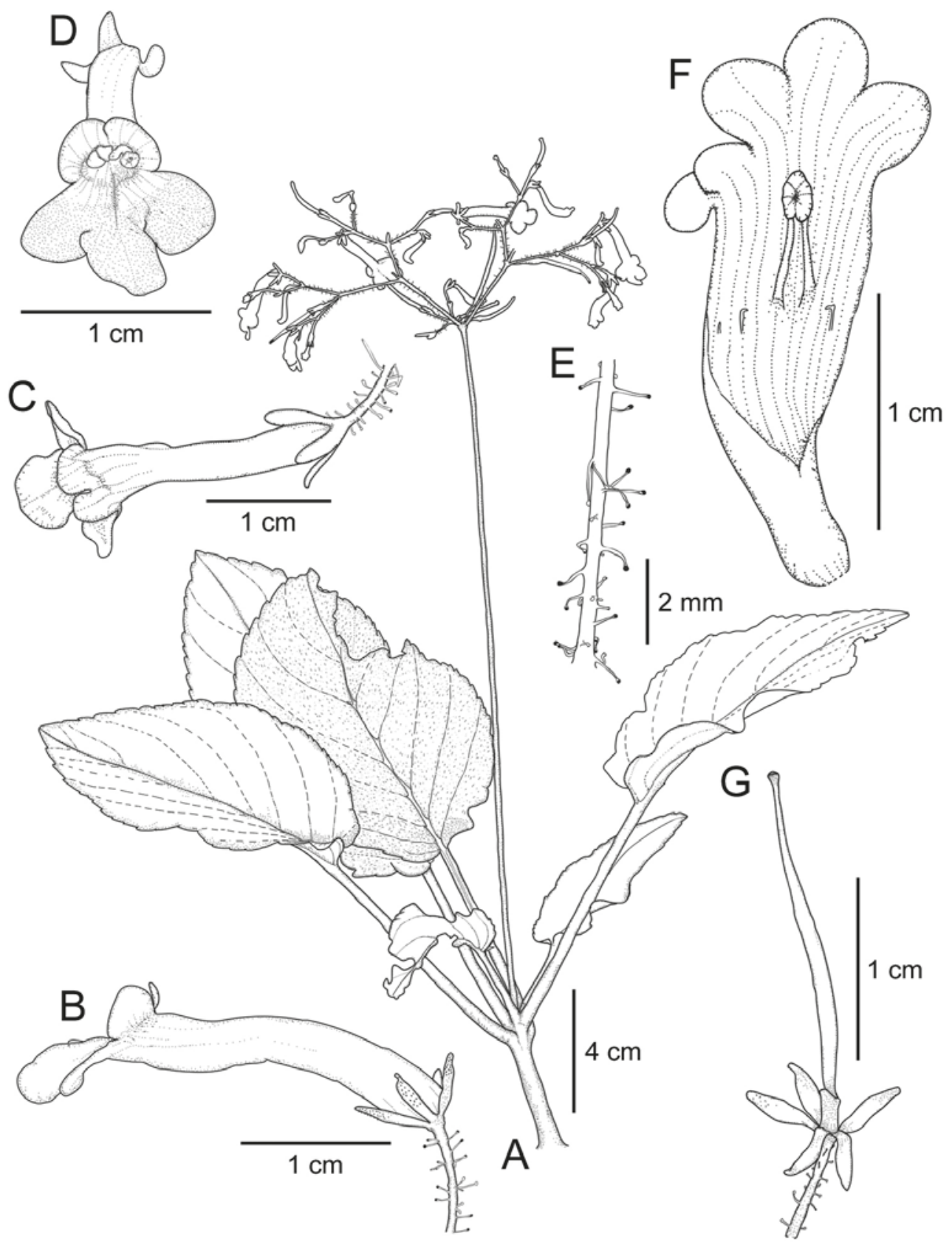

Fig. 2. Didymocarpus angustiflorus Souvann. \& Lanors. A. Habit. B. Flower (lateral view). C. Flower (top view). D. Flower (front view). E. Pedicel showing the multicellular glandular hairs. F. Corolla tube partly opened out to show stamens and staminodes. G. Pistil and calyx. All from Lanorsavanh et al. SL 1975. Drawn by K. Souvannakhoummane. 
Distribution. Central Laos (known only from the type locality in Phou Khao Khouay National Protected Area).

Habitat and phenology. Didymocarpus angustiflorus grows on moist rocks in evergreen forest, along with Globba sp., Monolophus sp. (Zingiberaceae), Sonerila sp. (Melastomataceae), Begonia hymenophylla Gagnep. (Begoniaceae) and some ferns. Flowering from July to August and fruiting from September to October (observed from cultivation).

Etymology. The specific epithet refers to its narrow cylindrical corolla tube.

Vernacular name. คงาแภขูอดมอง (Dok Kea Loth Mouang).

Provisional IUCN conservation assessment. Didymocarpus angustiflorus is currently known only from a single population located within Phou Khao Khouay National Protected Area, where we collected the above type specimens. The area of Phou Khao Khouay National Protected Area is about 2,000 $\mathrm{km}^{2}$, which can be taken as the EOO, but no threats have been observed. The population, however, comprises only about 100 mature individuals. We, therefore, assess the status of this species as Endangered (EN) under IUCN criterion D.

Notes. This species is also similar to Didymocarpus yunnanensis (Franch.) W.W.Sm. from China in habit, leaf shape and flower colour and shape, but is distinguished by its shorter stem, calyx lobes free to the base and with glands outside (vs calyx with 2-4 $\mathrm{mm}$ long tube, with 1-2 mm long lobes and outside sparsely glandular puberulent in D. yunnanensis), and corolla salverform and glabrous (vs corolla narrowly funnelform and sparsely pubescent outside in D. yunnanensis) (Wang et al., 1998).

2. Didymocarpus bolavenensis Souvann., Soulad. \& Phonep., sp. nov.

Morphologically similar to Didymocarpus inflatus J.F.Maxwell \& Nangngam from Thailand, in habit, ovate lamina, campanulate glabrous calyx, and cylindric ovary, but differs in the salverform to narrowly funnelform corolla which is $3-3.5 \mathrm{~cm}$ long, lobes purple with white lines in the mouth (vs funnelform, $4 \mathrm{~cm}$ long, lobes violet with dark violet-reddish lines in mouth), and broadly reniform corolla lobes (vs lobes suborbicular). - TYPE: Laos, Champasak Province, Paksong District, Dong Houa Sao National Protected Area, Bolaven Plateau Area, 1260 m, 1504'24.8'N 106 $12^{\prime} 22.5^{\prime \prime} \mathrm{E}$, 16 September 2020, Souladeth, Phonepaseuth, Vongthavone \& Souvannakhoummane L3880 (holotype FOF; isotypes HNL, KAG). (Fig. 3, 4D, E)

Deciduous, epilithic, perennial herbs, 20-35 cm tall including inflorescences. Stems $1.5-3.5 \mathrm{~mm}$ in diam. at base, erect, green, densely villous, with $2-4$ nodes, internodes of the basal part of stem 3.5-5.5 cm long, middle part 6-9 cm long, the uppermost $0.3-2$ $\mathrm{cm}$ long. Leaves solitary at the base, opposite from the middle to the top, anisophyllous 


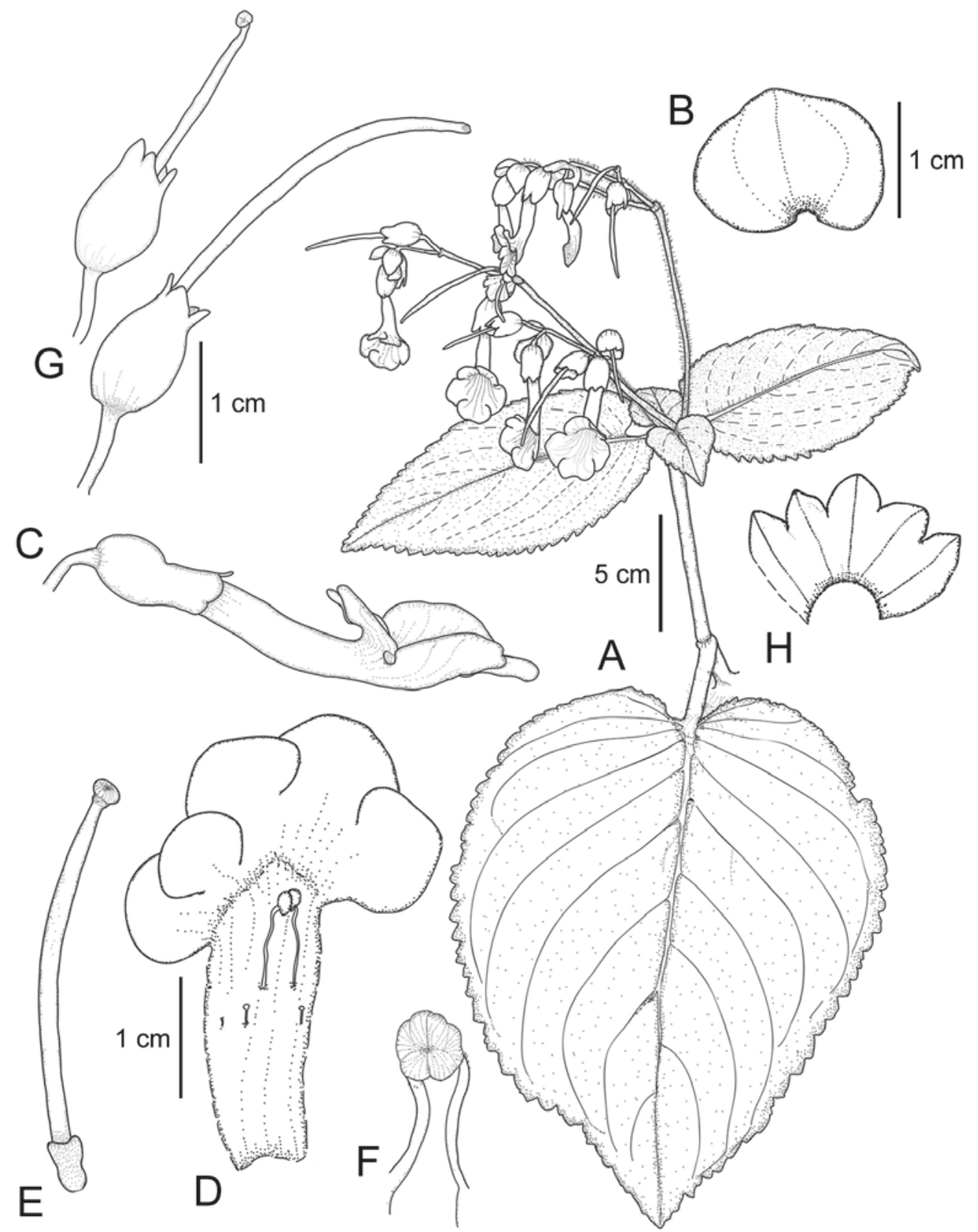

Fig. 3. Didymocarpus bolavenensis Souvann., Soulad. \& Phonep. A. Habit. B. Bract. C. Flower (lateral view). D. Corolla opened out showing stamens and staminodes. E. Pistil. F. Stamens. G. Calyx and pistil. H. Calyx opened out. All from Souladeth et al. L3880. Drawn by K. Souvannakhoummane. 
in a pair; petioles $2-5.5 \mathrm{~cm}$ long, or subsessile at stem apex, green, multicellular glandular pubescent; lamina chartaceous, ovate to ovate-elliptic, 4-12 × 1.2-9.5 $\mathrm{cm}$, apex acute, base subsymmetrically cordate, obtuse to cuneate, margin serrate, adaxially dark green, densely white multicellular eglandular puberulent, abaxially light green, sparsely white multicellular glandular puberulent, densely puberulent on veins; venation pinnate, with 4-10 pairs of secondary veins, prominent abaxially. Inflorescences axillary near top of the stem, cymose, 4-16-flowered; peduncle slender, 6-6.8 cm long, 1-1.2 $\mathrm{mm}$ in diam. at base, reddish green, multicellular glandular pubescent; bracts paired reniform, 10-12 × 10-18 mm, apex rounded to acute, margin entire, pale purple to pinkish, glabrous; pedicels 3-9 $\mathrm{mm}$ long, $0.3-0.6 \mathrm{~mm}$ in diam., pink-reddish to pale green, glabrous. Calyx campanulate, $8-13 \mathrm{~mm}$ long, light purple, glabrous, 5-lobed; tube 6-10 $\mathrm{mm}$ long, 6-8 $\mathrm{mm}$ in diam.; lobes subequal, ovatetriangular, 2-3 $\times 1-2 \mathrm{~mm}$, apex acute to rounded. Corolla salverform to narrowly funnelform, 3-3.5 cm long, tube light pink outside, lobes purple with white lines inside the mouth, glabrous on both sides; tube $2.4-2.8 \mathrm{~cm}$ long, 3-4 mm in diam.; limb distinctly 2-lipped, 2 lobes of the upper lip broadly reniform, 4-5 $\times 5-7 \mathrm{~mm}$, apex rounded, 3 lobes of the lower lip broadly reniform, 4.5-5.5 $\times 6.5-8 \mathrm{~mm}$, apex rounded. Fertile stamens 2, inserted 1-1.2 cm above the base of the corolla; filaments slender, 7-10 mm long, white, glandular puberulent near apex and connectives; anthers coherent by their adaxial surfaces, ellipsoidal, 2.5-3 $\mathrm{mm}$ long, 1.5-2 $\mathrm{mm}$ in diam., white, tips and bases rounded, white-bearded; staminodes 3, filiform, inserted at 4-5 $\mathrm{mm}$ below the stamens, white, glabrous, 2 lateral staminodes 2.5-3.5 mm long, apex thick, middle one c. $1.5 \mathrm{~mm}$ long, apex capitate. Disc cylindrical, c. $2 \mathrm{~mm}$ high, white, glabrous, margin undulate. Pistil $2.5-2.8 \mathrm{~cm}$ long; ovary cylindrical, pale green, white towards the base, $2.2-2.4 \mathrm{~cm}$ long, $1-1.2 \mathrm{~mm}$ in diam., glabrous; style continuous with the top of the ovary, c. $2 \mathrm{~mm}$ long, c. $1 \mathrm{~mm}$ in diam., greenish, glabrous; stigma capitate, c. $1.4 \mathrm{~mm}$ in diam., concave at apex, greenish, glabrous. Capsule straight, cylindrical, $2.8-3.2 \mathrm{~cm}$ long, $1.2-1.5 \mathrm{~mm}$ in diam., green with brown spots, turning brown when mature, glabrous, longitudinally dehiscent. Seeds unknown.

Distribution. Southern Laos (so far known only from the Bolaven Plateau).

Habitat and phenology. Didymocarpus bolavenensis grows on a wet and shaded table rock located near a stream in lower montane evergreen forest. The surface of the rock is covered with humus formed from mosses and ferns. Flowering from August to September and fruiting from September to November.

Etymology. The specific epithet of this taxon refers to the type locality.

Vernacular name. คงภแภม่องขละเอบ (Dok Kea Mouang Bolaven).

Provisional IUCN conservation assessment. Didymocarpus bolavenensis is currently known only from the type locality within Dong Houa Sao National Protected Area. The AOO is $4 \mathrm{~km}^{2}$ and c. 200 individuals grows there. However, this is possibly 

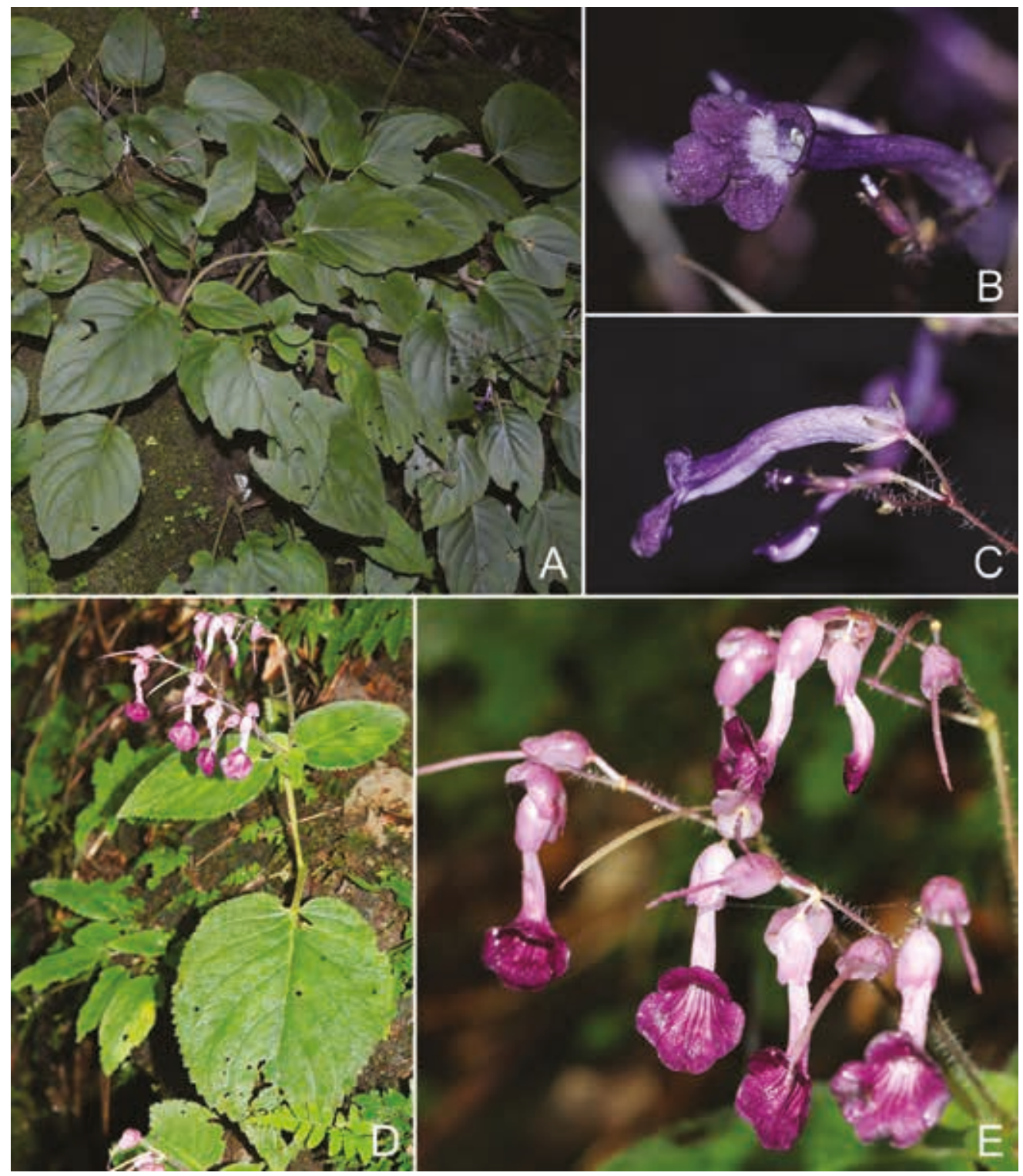

Fig. 4. A-C. Didymocarpus angustiflorus Souvann. \& Lanors. A. Habit. B. Flower (top view). C. Flower (lateral view). D, E. Didymocarpus bolavenensis Souvann., Soulad. \& Phonep. D. Habit. E. Flowers. A-C from Lanorsavanh et al. SL 1975; D, E from Souladeth et al. L3880. (Photos: A-C, S. Lanorsavanh; D, E, K. Souvannakhoummane)

an underestimate of the total population size. Dong Houa Sao National Protected Area coverers $1,100 \mathrm{~km}^{2}$ and this can be taken as the EOO. No threats have been observed to the population. On currently known information, we consequently assess the provisional conservation status of this species as Endangered (EN) under IUCN criterion D. 
Notes. This species is also similar to Didymocarpus adenocarpus C.E.C.Fisch., D. epithemoides B.L.Burtt and D. jaesonensis Nangngam \& J.F.Maxwell; it differs from D. adenocarpus in having stem densely villous, calyx campanulate, light purple and filaments glandular puberulent near apex (vs stem sparsely pubescent, calyx narrowly funnelform, whitish and filaments glabrous in D. adenocarpus) (Prasanna \& Gowda, 2020 ), from $D$. epithemoides in having bracts $10-12 \times 10-18 \mathrm{~mm}$, calyx tube $6-10 \times$ 6-8 $\mathrm{mm}$ and style glabrous (bracts $5 \times 5 \mathrm{~mm}$, calyx tube c. $5 \times 4 \mathrm{~mm}$ and style covered with glandular unicellular hairs in D. epithemoides), and from $D$. jaesonensis in having bracts reniform, 10-12 × 10-18 mm, pale purple to pinkish, calyx light purple, and corolla tube $2.4-2.8 \mathrm{~cm}$ long, $3-4 \mathrm{~mm}$ in diam. (vs bracts broadly rounded, c. $8 \times 8$ $\mathrm{mm}$, violet, calyx violet, corolla tube c. $2 \mathrm{~cm}$ long, c. $2 \mathrm{~mm}$ in diam. in D. jaesonensis) (Nangngam \& Maxwell, 2013).

\section{Didymocarpus laoticus Souvann. \& Lanors., sp. nov.}

The new species is morphologically similar to Didymocarpus sinoindicus N.S.Prasanna, Lei Cai \& V.Gowda in habit, ovate lamina and ovary shape, but differs in having calyx 10-13 mm long, white, glabrous (vs 4-6 mm long, cream-white to greenish yellow, covered with peltate pigment glands outside), corolla 30-32 mm long, white with dark blue in the mouth (vs corolla $8.5-12 \mathrm{~cm}$ long, cream-white to greenish yellow with purple striations in the mouth), and ovary glabrous (vs ovary covered with peltate pigment glands). - TYPE: Laos, Bolikhamxai Province, Thaphabath District, Phou Khao Khouay National Protected Area, 400 m, 18 $27^{\prime} 51.2^{\prime \prime} \mathrm{N} 103^{\circ} 18^{\prime} 13.3^{\prime \prime} \mathrm{E}, 29$ August 2020, Lanorsavanh, Souvannakhoummane \& Yuangyayear SL 1976 (holotype HNL; isotypes FOF, KKU). (Fig. 5, 7A-C)

Deciduous, epilithic, perennial herbs, 10-20 cm tall including inflorescences. Stems 9.5-12 $\mathrm{mm}$ in diam., erect to ascending, pale green, densely white multicellular pubescent, with 1(-3) nodes, internodes $0.5-12 \mathrm{~cm}$ long. Leaves occasionally solitary at the base, opposite, often crowded at the shoot apex, anisophyllous in a pair; petiole 1-4 cm long or leaves subsessile at shoot apex, green, multicellular pubescent; lamina chartaceous, ovate to broadly lanceolate, 7.5-16 $\times 4-10 \mathrm{~cm}$, apex acute, base slightly asymmetrically subcordate to cuneate, margin serrate, adaxially dark green, densely white multicellular pubescent, abaxially light green, sparsely white multicellular pubescent except on veins which are densely white multicellular pubescent; venation pinnate, with 6-9 pairs of secondary veins, prominent abaxially. Inflorescences axillary near shoot apex, flowers solitary or cymose and 4-10-flowered; peduncle 10-12 mm long, $0.5-0.7 \mathrm{~mm}$ in diam., pale green, multicellular glandular puberulent; bracts paired reniform, 7-8.5 × 10-12 mm, apex obtuse, margin entire, white to pale green, glabrous; pedicels 3-4 mm long, green, multicellular glandular puberulent to glabrous. Calyx narrowly campanulate, 10-13 mm long, white, glabrous, tube 8-11 $\mathrm{mm}$ long, 4-6 mm in diam., lobes 5, equal, ovate-triangular to semi-orbicular, 1-1.5 $\times$ 1-2 mm, apex rounded. Corolla salverform to narrowly funnelform, 30-32 mm long, glabrous, white with dark blue patch on the lip; tube 18-22 mm long, 2-2.5 mm 


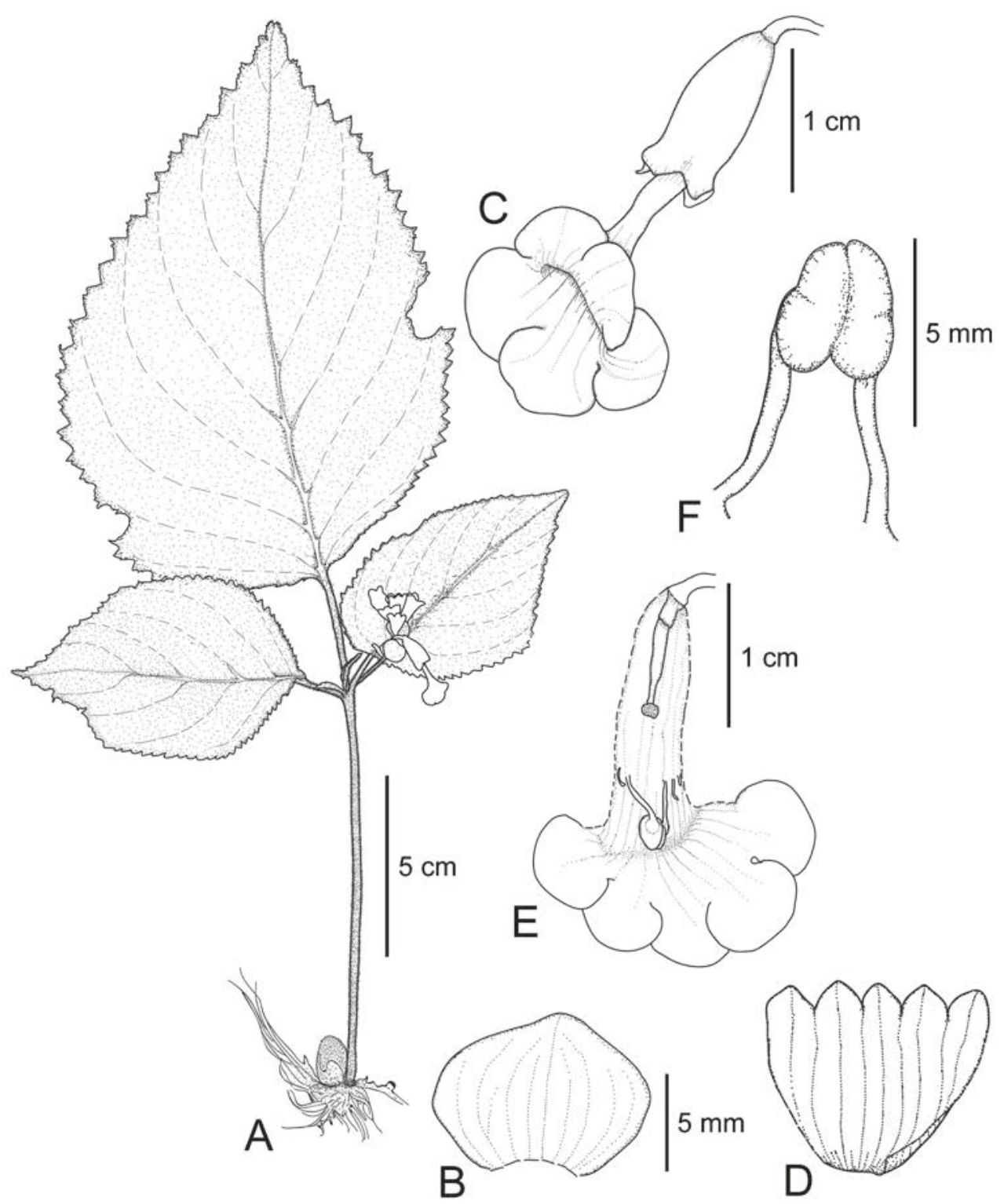

Fig. 5. Didymocarpus laoticus Souvann. \& Lanors. A. Habit. B. Bract. C. Flower (top view). D. Calyx opened out. E. Dissected corolla tube showing stamens and staminodes. F. Stamens. All from Lanorsavanh et al. SL 1976. Drawn by K. Souvannakhoummane.

in diam.; limb distinctly 2-lipped, adaxial lip 2-lobed, lobes broadly reniform, 3-4 × 6-7 mm, apex rounded; abaxial lip 3-lobed, lobes semi-orbicular or broadly reniform, 3-4 × 5-6.5 mm, apex rounded. Fertile stamens 2, inserted 13-15 $\mathrm{mm}$ above the base of the corolla; filaments $2-3 \mathrm{~mm}$ long, slender, white, glabrous; anthers coherent 
by adaxial surfaces, brownish, oblong-elliptic to globose, c. $2 \times 2 \mathrm{~mm}$, tip and base rounded; staminodes 3 , filiform, inserted 1-2 mm below the stamens, white, glabrous, 2 lateral staminodes 2-2.5 mm long, thick, at apex acute, middle one c. $1 \mathrm{~mm}$ long, apex capitate. Disc cylindrical, c. $2 \mathrm{~mm}$ high, white, glabrous, margin irregular. Pistil 8-10 mm long; ovary cylindrical, 5-6 $\mathrm{mm}$ long, $1-1.2 \mathrm{~mm}$ in diam., pale green, white towards the base, glabrous; style continuous with the top of the ovary, c. $2 \mathrm{~mm}$ long, c. $2 \mathrm{~mm}$ in diam., white to greenish, glabrous; stigma irregular capitate, c. $1 \times 1 \mathrm{~mm}$, concave, papillose. Capsule and seeds unknown.

Distribution. Central Laos (Phou Khao Khouay National Protected Area in Bolikhamxai Province).

Habitat and phenology. It was found growing on wet rocks near a small stream in mixed deciduous forest where Dendrocalamus membranaceus Munro (Poaceae) is dominant. Flowering from late July to August.

Etymology. The specific epithet refers to where the type material was collected.

Vernacular name. องาแภวาอใจข้ๆ (Dok Kea Khao Jai Fa).

Provisional IUCN conservation assessment. Didymocarpus laoticus is currently known only from a single locality within Phou Khao Khouay National Protected Area where there are about 10 individuals. Although more individuals/populations might be found with additional field surveys, based on current data it is assessed here as Critically Endangered (CR) under IUCN criterion D. Further intensive surveys are needed to accurately know the number of populations/individuals for its conservation.

Notes. This species is also similar to Didymocarpus kerrii Craib, but differs in having lamina asymmetrical, peduncle shorter, $10-12 \mathrm{~mm}$, calyx longer, $10-13 \mathrm{~mm}$, glabrous, corolla tube whitish (vs lamina symmetrical, peduncle $20-50 \mathrm{~mm}$, calyx c. $5 \mathrm{~mm}$, multicellular glandular hairy, corolla tube violet in D. kerrii (Nangngam \& Maxwell, 2013)).

\section{Didymocarpus trilobus Souvann. \& Phonep., sp. nov.}

The new species is morphologically similar to Didymocarpus albiflorus Souvann. \& Phonep., in having corolla funnelform, but differs in often lacking larger basal leaves (vs with larger basal leaves in D. albiflorus), calyx campanulate and 3-lobed (vs funnelform and 5-lobed), corolla dark purple (vs white), and ovary glabrous (vs sparsely glandular puberulent). - TYPE: Laos, Vientiane Province, Thoulakhom District, Vangheua Village, Phou Khao Khouay National Protected Area, 300 m, $18^{\circ} 21^{\prime} 33.8^{\prime \prime N} 102^{\circ} 48^{\prime 2} 23.0^{\prime \prime E}, 27$ July 2020, Souvannakhoummane, Phonepaseuth, Pathoumthong, Phothilart, Kiaosouvath, Sookkhasing, Manyvong \& Vongthavone KS 1010 (holotype FOF; isotype HNL). (Fig. 6, 7D, E) 




Fig. 6. Didymocarpus trilobus Souvann. \& Phonep. A. Habit. B. Flower (lateral view). C. Flower (front view). D. Corolla tube opened out showing stamens and staminodes. E. Calyx opened out. F. Pistil. G. Stamens. All from Souvannakhoummane et al. KS1010. Drawn by K. Souvannakhoummane. 
Deciduous, epilithic, perennial herbs, 12-29 cm tall. Stems 2.5-3 mm in diam., erect, pale green at base, gradually reddish green towards apex, densely white multicellular glandular pubescent, with 3-4 nodes; longest internode at the base of the stem 6.5-12 $\mathrm{cm}$ long, the internode in the middle $4.5-6 \mathrm{~cm}$ long, the shortest internode at the apex $0.3-0.6 \mathrm{~cm}$ long. Leaves opposite, anisophyllous in a pair; petiole $0.7-5 \mathrm{~cm}$ long, or subsessile for apical leaves, reddish brown, multicellular glandular pubescent; lamina chartaceous, narrowly ovate-elliptic to oblong-elliptic, $4.5-7.5 \times 2-5.4 \mathrm{~cm}$, apex acute, base asymmetrically subcordate to cuneate, margin serrate, adaxially dark green, densely white multicellular glandular puberulent, abaxially lightly green, glabrous except sparsely white multicellular glandular puberulent on veins; venation pinnate, with 4-7 pairs of secondary veins, prominent abaxially. Inflorescences axillary near shoot apex, cymose, 1-4-flowered; peduncle slender, 4-6 cm long, 0.7-1 mm in diam., reddish green, glabrous; bracts paired, lanceolate-orbicular to ovate-lanceolate, 3.5-5 $\times 2.5-4.5 \mathrm{~mm}$, apex rounded to acute, margin entire, green, glabrous; pedicels 8-12 $\mathrm{mm}$ long, $0.5-0.7 \mathrm{~mm}$ in diam., reddish green, glabrous. Calyx campanulate, 9-14 mm long, green, glabrous, tube 6-9 mm long, 8-10 $\mathrm{mm}$ in diam., lobes triangular, 3-lobed, upper lobe broadly semi-orbicular, 3-5 $\times 7-9 \mathrm{~mm}$, apex emarginate to obtuse, 2 lower lobes narrowly semi-orbicular, 3-5 × 4-6 mm, apex acute. Corolla funnelform, 2.8$3.4 \mathrm{~cm}$ long, dark purple, paler towards to base, glabrous, tube $2.5-2.9 \mathrm{~cm}$ long, $1-1.3$ $\mathrm{cm} \mathrm{cm}$ in diam. at throat; limb distinctly 2-lipped, adaxial lip 2-lobed, lobes broadly reniform, 3.5-4 × 7-8.5 mm, apex rounded, abaxial lip 3-lobed, lobes semi-orbicular, 3-3.4 $\times 6-8 \mathrm{~mm}$, apex rounded. Stamens 2 , inserted $1.2-1.4 \mathrm{~cm}$ above the base of the corolla; filaments slender, 6-7 mm long, white, glabrous to glandular puberulent near apex; anthers coherent by adaxial surfaces, brownish, oblong-elliptic, 2.9-3.2 × 1.7-2 $\mathrm{mm}$, tip and base rounded, white-bearded; staminodes 3 , filiform, inserted 2-3 mm below the stamens, white, glabrous, 2 lateral staminodes 3-3.4 mm long, apex thick, central one c. $2 \mathrm{~mm}$ long, apex capitate. Disc tubular, c. $1.2 \mathrm{~mm}$ high, white, glabrous, margin slightly undulating. Pistil $2.2-2.6 \mathrm{~cm}$ long; ovary cylindrical, 2-2.4 cm long, $1.2-1.4 \mathrm{~mm}$ in diam., pale green, white towards the base, glabrous; style continuous with the top of the ovary, c. $1 \mathrm{~mm}$ long, c. $1 \mathrm{~mm}$ in diam., greenish, glabrous; stigma irregularly capitate, c. $1.2 \times 1.2 \mathrm{~mm}$, concave at apex, greenish, glabrous. Capsule straight, cylindrical, linear, 3.2-4.5 cm long, 1.5-2.5 $\mathrm{mm}$ in diam., turning brown when ripe, dehiscing loculicidally into 2 valves. Seeds unknown.

Distribution. Central Laos (so far known from two small populations in Phou Khao Khouay National Protected Area, in Vientiane and Bolikhamxai).

Habitat and phenology. It is common in seasonal deciduous forest mixed with bamboo at an altitude of $300 \mathrm{~m}$ and grows on wet rocks with mosses and Adiantum sp. (Adiantaceae). Flowering from July to August and fruiting from August to October. The above-ground part of the plants dries up completely in January (recorded from cultivated living collection).

Etymology. The species epithet of this taxon refers to the three lobes of the calyx due to the upper lobes fusing into a single lobe. 

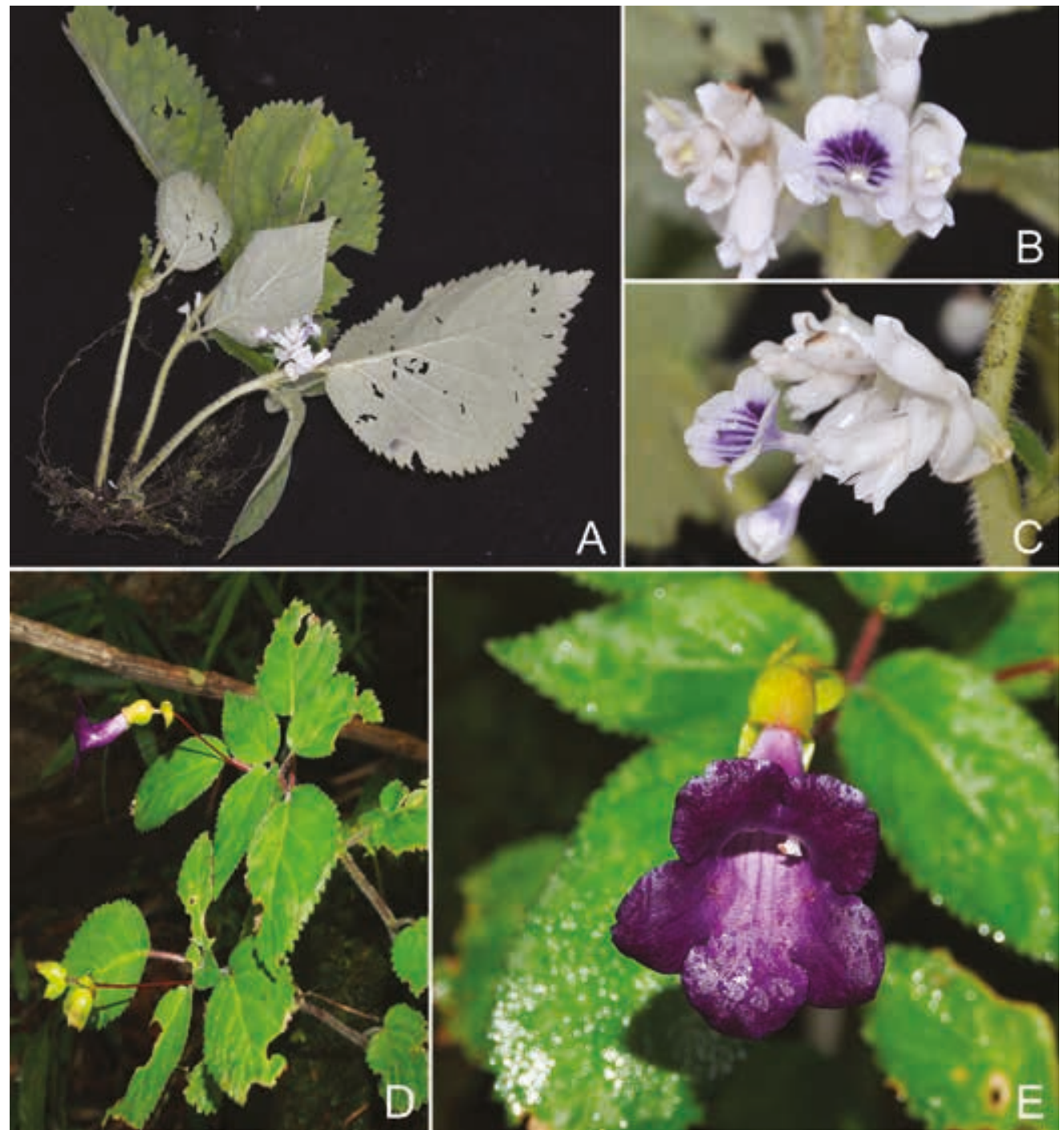

Fig. 7. A-C. Didymocarpus laoticus Souvann. \& Lanors. A. Habit. B. Flower (front view). C. Flower (lateral view). D, E. Didymocarpus trilobus Souvann. \& Phonep. D. Habit with flower lateral view. E. Flower (front view). (Photos: A-C, S. Lanorsavanh; D, E, K. Souvannakhoummane)

Vernacular name. คราแภม่องใขทย่ (Dok Kea Mouang Yai).

Provisional IUCN conservation assessment. The specimens of Didymocarpus trilobus were collected only from the two localities within Phou Khao Khouay National Protected Area, where the two populations comprise more than 300 individuals in total. The AOO is calculated as $4 \mathrm{~km}^{2}$. However, the population size and AOO is likely to be underestimated since we observed this species widely and it was commonly found within the protected area during our field work. The area of Phou Khao Khouay 
National Protected Area is about 2,000 $\mathrm{km}^{2}$ and this can be taken as the EOO. The habitat is well-protected and the populations are stable. Given this situation, it is assessed as Least Concern (LC) at present.

Additional specimens examined. LAOS: Bolikhamxai: Thaphabath District, Phou Khao Khouay National Protected Area, $18^{\circ} 27^{\prime} 28.7^{\prime \prime} \mathrm{N} 103^{\circ} 18^{\prime} 16.8^{\prime \prime} \mathrm{E}, 300$ m, 15 Aug 2020, Lanorsavanh et al. SL 1971 (FOF, HNL, KKU, QBG).

5. Hemiboea olivifolia Souvann. \& Tagane, sp. nov.

Morphologically similar to Hemiboea cavaleriei H.Lév., but differs in having lamina succulent and dark waxy olive-green adaxially, and corolla white and glabrous outside (vs lamina herbaceous in $H$. cavaleriei var. cavaleriei, lamina papery to thinly papery in $H$. cavaleriei var. paucinervis W.T.Wang \& Z.Y.Li and both varieties non-waxy olive-green on adaxial surface; corolla outside pale yellow and sparsely glandular puberulent). - TYPE: Laos, Louangphabang Province, Louangphabang District, Pha Nam Yard Forest Reserve Area, 300 m, 19 $51^{\prime} 44.43^{\prime \prime N} 102^{\circ} 02^{\prime} 55.49^{\prime \prime} \mathrm{E}, 26$ November 2012, Souvannakhoummane, Gadella, Inphavong \& Souksavath KS 493 (holotype NHL; isotypes FOF, QBG). (Fig. 8, 10A-C)

Lithophytic, perennial herbs, up to $60 \mathrm{~cm}$ tall. Stems creeping at base becoming erect at middle, 30-60 cm long, 1-2 cm in diam., succulent, olive-green, pale green near apex with brown-purple spots, glabrous, with 4-7 nodes, internodes 3-5 cm long, swollen at nodes. Leaves opposite, decussate, succulent; petiole terete, 3-5 cm long, 2-5 mm in diam., succulent, glabrous; lamina elliptic to obovate, 10-18 $\times 4-7 \mathrm{~cm}$, apex acuminate, base cuneate, sometimes slightly oblique, margin weakly mucronate to entire, adaxially waxy olive-green, abaxially pale green, glabrous on both sides except veins pubescent when young; venation pinnate, with 4-6 pairs of secondary veins. Inflorescences cymose, axillary near stem apex, up to $5 \mathrm{~cm}$ long, 3-6-flowered; peduncle erect, up to $4 \mathrm{~cm}$ long, green, glabrous; involucral bracts spheroidal, $1-1.6 \mathrm{~cm}$ in diam., green, glabrous on both surfaces; pedicel absent or to $3 \mathrm{~mm}$ long, glabrous, brown. Calyx green-white, 5-lobed from the base; lobes subequal, linear-lanceolate, 6-8 $\times 2-2.5 \mathrm{~mm}$, glabrous on both sides. Corolla funnelform, 3-3.5 cm long, 1.2-1.5 $\mathrm{cm}$ in diam. at the limb, outside white, glabrous, inside yellowish-orange, spotted with 6-9 brown lines, sparsely glandular hairy, with a ring of hairs 4-7 $\mathrm{mm}$ above the corolla base; limb distinctly 2-lipped, 2 upper lobes semiorbicular, 10-12 $\times 4-9 \mathrm{~mm}$, apex rounded, 3 lower lobes ovate to lanceolate, 9-10 $\times$ 4-8 mm, apex rounded. Stamens 2 , inserted 10-12 $\mathrm{mm}$ above the corolla base; filaments up to $1.2 \mathrm{~cm}$ long, glabrous; anthers coherent apically or near apex, subglobose, c. $2 \mathrm{~mm}$ in diam.; staminodes 3 , glabrous, inserted at c. $12 \mathrm{~mm}$ above the corolla base, lateral 2 staminodes linear, c. 10 $\mathrm{mm}$ long, apex inflated, smaller one linear, c. $6 \mathrm{~mm}$ long, apex capitate. Disc ring-like, c. $2 \mathrm{~mm}$ high, margin entire. Pistil 16-17 mm long; ovary linear, c. $9 \mathrm{~mm}$ long, c. 2 $\mathrm{mm}$ in diam., glabrous; style c. $5 \mathrm{~mm}$ long; stigma capitate, thick, c. $1.5 \mathrm{~mm}$ in diam. Capsule plagiocarpic, cylindrical, 1.8-2.5 cm long, curved upwards from near base, glabrous, loculicidally dehiscent. Seeds ovoid, c. $1 \times 1.2 \mathrm{~mm}$, brownish. 


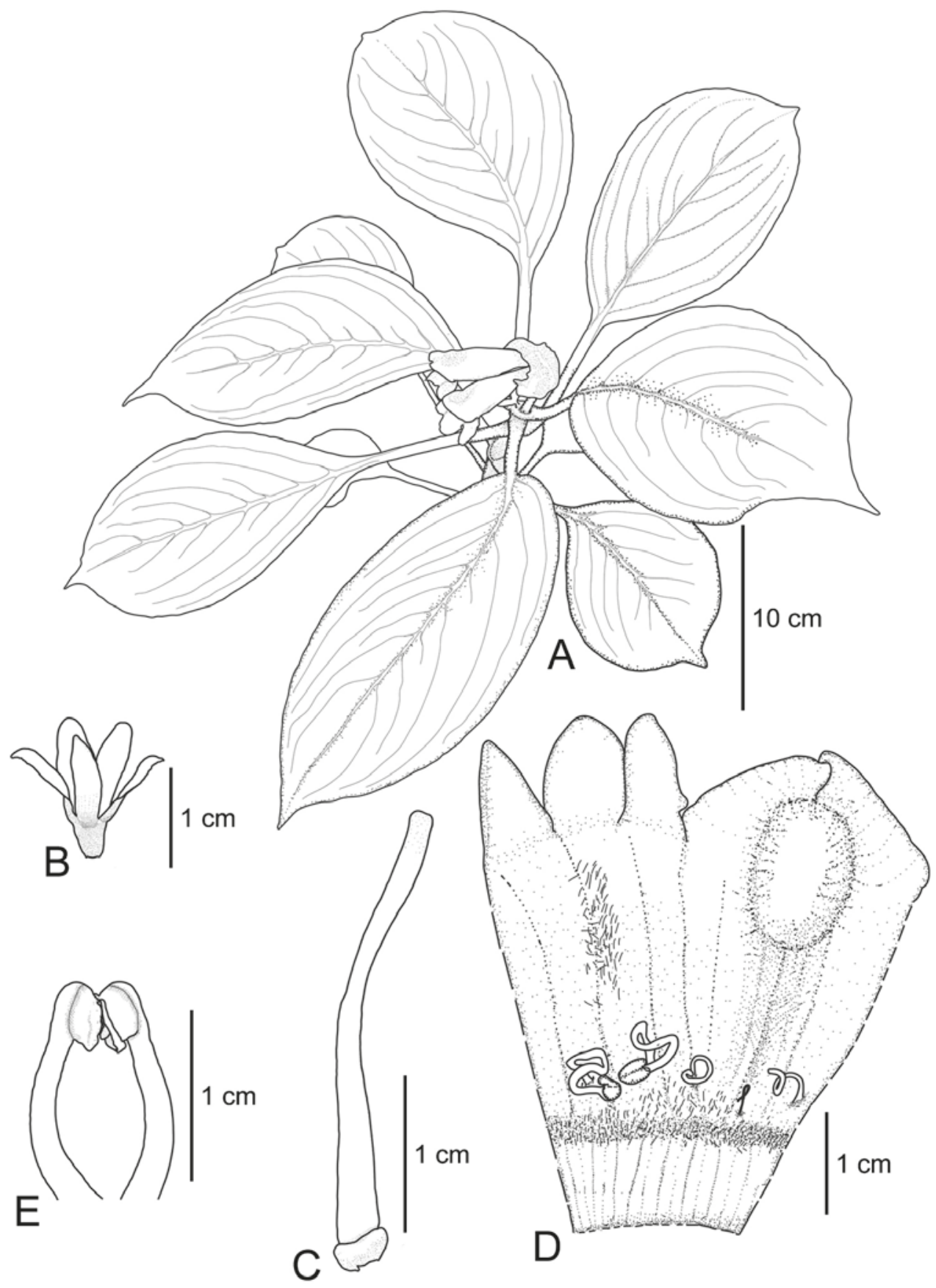

Fig. 8. Hemiboea olivifolia Souvann. \& Tagane. A. Habit. B. Calyx. C. Pistil. D. Corolla opened out showing stamens and staminodes. E. Stamens. All from Souvannakhoummane et al. KS493. Drawn by K. Souvannakhoummane. 
Distribution. Northern Laos (Pha Nam Yard Forest Reserve Area, Louangphabang Province).

Habitat and phenology. It grows on a limestone hill in deciduous forest, c. $300 \mathrm{~m}$ from the banks of the Mekong River, where the stable humidity, essential for the survival of this species, comes from the river. It occurs with Amorphophallus yunnanensis Engl. (Araceae), Impatiens parishii Hook.f. (Balsaminaceae), Dracaena sp. (Asparagaceae) and Asplenium sp. (Aspleniaceae). Flowering from October to November and fruiting in December.

Etymology. The specific epithet of this taxon refers to the olive-green upper leaf surface.

Vernacular name. องมละดัๆรึบ (La Khang Ngeurn).

Provisional IUCN conservation assessment. Hemiboea olivifolia is currently known only from 10 individuals at the type locality within Pha Nam Yard Forest Reserve Area. The nature reserve covers an area of only $10 \mathrm{~km}^{2}$ and is surrounded by more or less disturbed areas due to human activities. These areas may have originally included habitats suitable for this species. We therefore propose an assessment of Critically Endangered (CR B2ab(ii,iii), D).

Notes. Hemiboea olivifolia is also similar to H. angustifolia F.Wen \& Y.G.Wei but differs in lamina succulent, elliptic to obovate and dark olive-green on adaxial surface, corolla 3-3.5 cm long, outside white, glabrous, inside yellowish orange, spotted with 6-9 brown lines, sparsely glandular hairy and disc entire (vs lamina subcarnose or thinly leathery, narrowly lanceolate to lanceolate, corolla $4.8-5.4 \mathrm{~cm}$, outside greyish white or waxy-white, adaxially light purple, inside brownish yellow, outside adaxially glandular puberulent, outside abaxially extremely short pubescent to nearly glabrous, inside glabrous and disc margin repand (Wen et al., 2011)).

The genus Hemiboea, with more than 40 species and 6 varieties (Nguyen et al., 2019), is known from China and Vietnam, extending to southern Japan (Yaeyama Islands). Of the 40 species, 35 taxa are endemic to China (Wang et al., 1998; Nguyen et al., 2019). Our discovery is the first record of this genus in Laos.

6. Paraboea planiflora Souvann. \& Lanors., sp. nov.

Morphologically similar to Paraboea khaoyaica Kaitongsuk et al. in habit and in having an almost flat-faced corolla (Kaitongsuk et al., 2021), but differs in bracts broadly oblanceolate to oblong, calyx with a scattered glandular indumentum, and corolla minutely pubescent outside (vs bracts linear or lanceolate, calyx glabrous, and corolla glabrous in P. khaoyaica). - TYPE: Saysomboun Province, Longsan District, Phou Khao Khouay National Protected Area, 539 m, 18²7'37.6"N 10302'59.0"E, 15 August 2020, Lanorsavanh, Souvannakhoummane \& Xaiyavong SL 1970 (holotype HNL; isotypes FOF, KKU). (Fig. 9, 10D, E) 


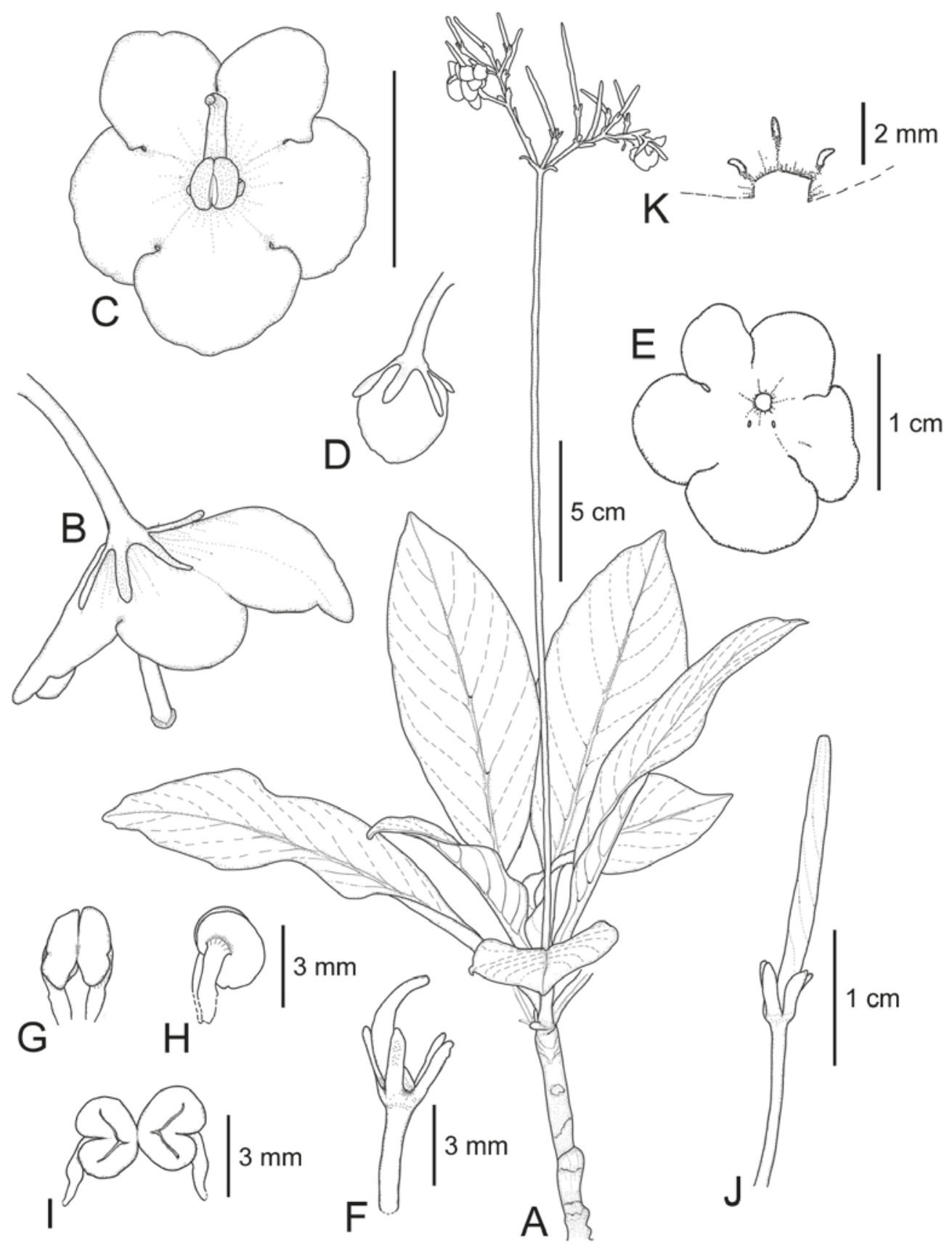

Fig. 9. Paraboea planiflora Souvann. \& Lanors. A. Habit. B. Flower later view. C. Flower front view. D. Flower bud. E. Corolla. F. Pistil and calyx. G. Stamens (front view). H. Stamens (lateral view). I. Stamens (top view). J. Young capsule with calyx and pedicel. K. Staminodes. All from Lanorsavanh et al. SL 1978. Drawn by K. Souvannakhoummane. 
Deciduous, lithophytic, perennial, caulescent herbs. Stems erect, 5-15 cm long, 0.8-1 $\mathrm{cm}$ in diam., densely covered with a thick layer of matted long and white hairs. Leaves opposite, decussate, densely arranged at the top of stems; petiole 2.5-6 cm long, covered with long simple hairs as on the stem; lamina narrowly elliptic to lanceolate, $10-14 \times 3.5-5 \mathrm{~cm}, 2-3$ times as long as wide, apex broadly acute to obtuse, base narrowly attenuate, margin entire or slightly undulate, medium green and hispid with a white arachnoid indumentum adaxially, pale green with a dense white arachnoid indumentum abaxially, with 7-9 pairs of secondary veins. Inflorescences axillary, compound pair-flowered cymes, longer than the leaves, (8-)15-35-flowered; peduncle 19-24 cm long, reddish purple, glabrous; bracts broadly oblanceolate to oblong, 5-8 $\mathrm{mm}$ long, apex rounded, margin entire, sparsely arachnoid or glabrous adaxially, white arachnoid abaxially; pedicel reddish purple, $7-15 \mathrm{~mm}$ long, erect to slightly pendulous, pubescent to glabrous. Flower bud white to pale lilac, 3-5 $\mathrm{mm}$ in diam. Calyx divided to base; lobes 5, oblong-lanceolate, 2-2.5 $\mathrm{mm}$ long, apex obtuse, light green to reddish, glabrous or with scattered glandular indumentum. Corolla short-tubed and almost flatfaced, bilabiate, pale lilac; tube c. $1 \mathrm{~mm}$ long, minutely pubescent outside, glabrous inside; limb indistinctly 2-lipped, upper lip 2-lobed, lobes broadly elliptic, 4-4.5 $\times$ 5-6 mm, apex rounded, lower lip 3-lobed, lobes ovate-orbicular, 4.5-5 × 5-6.5 mm, apex rounded. Stamens inserted at c. $1 \mathrm{~mm}$ from corolla base; filaments c. $2 \mathrm{~mm}$ long, glabrous or glandular hairy; anthers connected at apex, c. $2.5 \times 2.5 \mathrm{~mm}$, yellow, thecae subparallel and reniform, dehiscing longitudinally; staminodes 3, filiform, lateral $2 \mathrm{c}$. $1 \mathrm{~mm}$ long, white, glabrous, middle one c. $1.4 \mathrm{~mm}$ long. Pistil 8-9 mm long; ovary narrowly oval, c. $6 \mathrm{~mm}$ long, pale green, glabrous; style c. $2 \mathrm{~mm}$ long, glabrous, curved; stigma capitate, c. $0.2 \mathrm{~mm}$ in diam., minute papillate. Capsule green, cylindric, c. $20 \times$ $2 \mathrm{~mm}$, glabrous, twisted in dry specimens. Seeds oval, numerous, brown.

Distribution. Central Laos (Phou Khao Khouay National Protected Area, in Bolikhamxai and Saysomboun Province).

Habitat and phenology. Paraboea planiflora grows on open to semi-shaded rocks in mixed deciduous forest with bamboo, and is often common near streams. Flowering from July to August and fruiting from August to September.

Etymology. The specific epithet of this taxon refers to the flat-faced corolla.

Vernacular name. २จล๊สิ (Sa Leu Si).

Provisional IUCN conservation assessment. Paraboea planiflora is currently known only from two populations, both of which are located within Phou Khao Khouay National Protected Area covering about $2,000 \mathrm{~km}^{2}$. The two populations include more than 100 individuals and have an AOO of $8 \mathrm{~km}^{2}$. However, it is likely that both the population size and $\mathrm{AOO}$ are underestimated as this species was widely and commonly seen in the protected area in our field observations. No threats have been identified. Therefore, we assess this species as Least Concern (LC) at the present. 


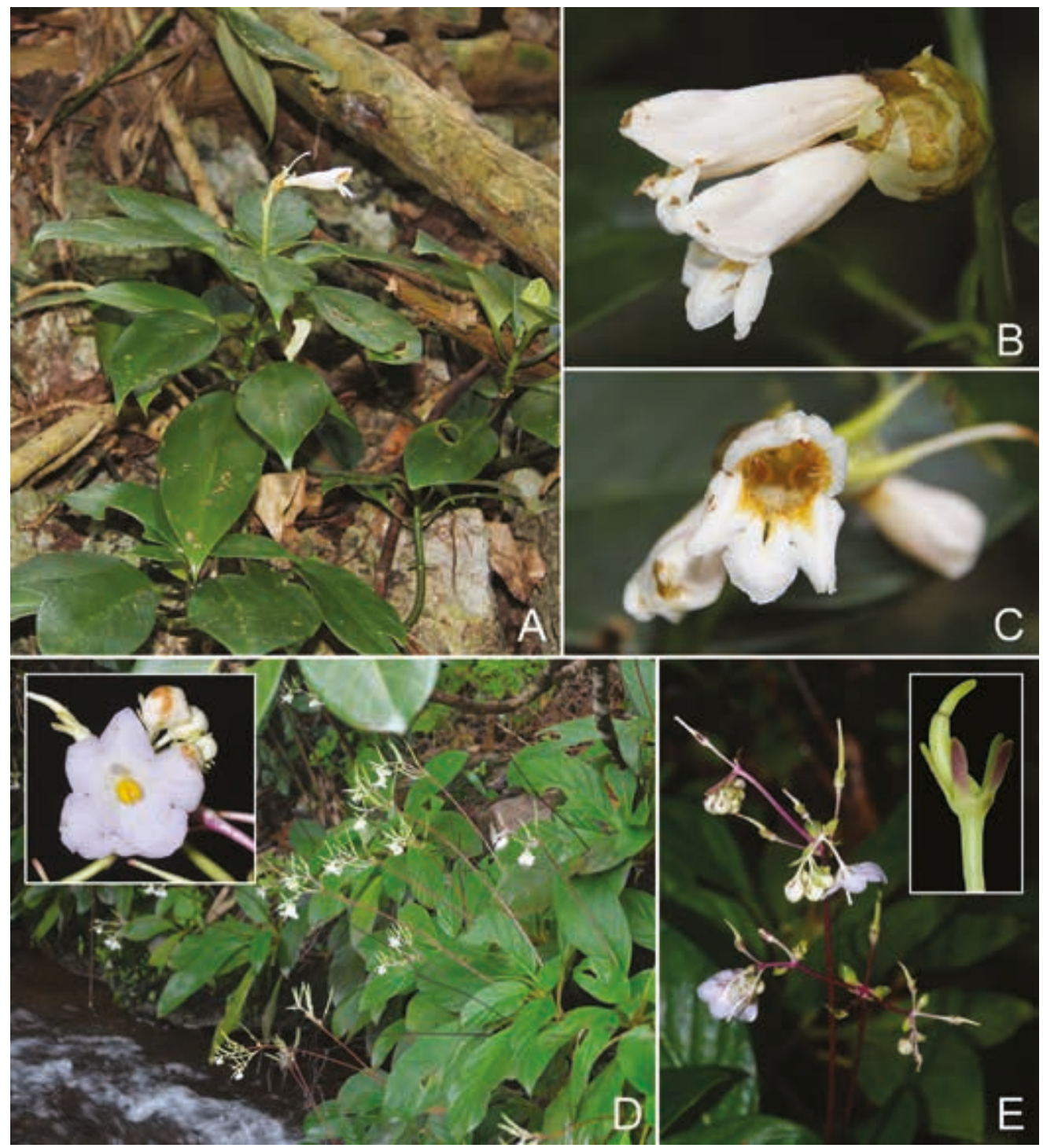

Fig. 10. A-C. Hemiboea olivifolia Souvann. \& Tagane. A. Habit. B. Flowers (lateral view). C. Flower (front view). D, E. Paraboea planiflora Souvann. \& Lanors. D. Habit. Inset: Flower (front view). E. Part of Inflorescence. Inset: Pistil with calyx and pedicel. A-C from Souvannakhoummane et al. KS493; D, E from Lanorsavanh et al. SL 1978. (Photos: A-C, K. Souvannakhoummane; D, E, S. Lanorsavanh)

Additional specimens examined. LAOS: Bolikhamxai: Thaphabath District, Phou Khao Khouay National Protected Area, 267 m, 18 $27^{\prime} 22.7^{\prime \prime} \mathrm{N} 103^{\circ} 18^{\prime} 19.7^{\prime \prime} \mathrm{E}, 15$ Aug 2020, Lanorsavanh et al. SL 1978 (FOF, HNL).

Notes. The flat-faced corolla of this species is similar to species of Middletonia C.Puglisi, but Paraboea differs from Middletonia in mostly having a larger habit, in the anther orientation and the ovary lacking sessile glands (Fig. 10E) (Möller et al., 2017; Puglisi 
\& Middleton, 2017b). Paraboea planiflora is also similar to P. quercifolia Triboun in having an almost flat-faced corolla, but differs in the peduncle reddish purple, glabrous, calyx lobes 5, oblong-lanceolate, glabrous or with scattered glandular indumentum, and corolla pale lilac (vs peduncle red, with dense red multicellular glandular hairs; calyx lobes narrowly ovate, covered with dense tiny glandular hairs; corolla violetblue in P. quercifolia) (Triboun \& Middleton, 2012). The local people boil dry leaves to make a tea which is drunk as a restorative tonic after childbirth.

\section{New species records}

1. Aeschynanthus bracteatus Wall. ex A.DC., Prodr. 9: 261 (1845); Pellegrin, Fl. IndoChine 4: 494 (1930); Wang et al., Fl. China 18: 378 (1998); Middleton, Edinburgh J. Bot. 66(3): 402 (2009). - Trichosporum bracteatum (Wall. ex A.DC.) Kuntze, Revis. Gen. P1. 2: 477 (1891). - TYPE: India, Pundua, Wallich s.n. [EIC 794] (lectotype G-DC, designated by Middleton (2009); isolectotypes BM, G, K [K000096767*], K-W, L, S). (Fig. 11A)

Specimens examined. LAOS: Saysomboun: Anouvong District, Phou Bia Mountain, $2578 \mathrm{~m}$, $18^{\circ} 58^{\prime} 28.6^{\prime \prime} \mathrm{N} 103^{\circ} 08^{\prime} 17.6^{\prime \prime} \mathrm{E}, 17$ Oct 2019, Lanorsavanh et al. SL 1751 (HNL, Herbarium of National University of Laos). Bolikhamxai: Khamkeut District, Naheung Village, Phou Phou Chom Voy Provincial Protected Area, 1023 m, 18²5'23.3"N 10458'56.7"E, 10 Oct 2020, Lanorsavanh et al. SL 2038 (HNL, Biology-National University of Laos).

Notes. This species is an epiphyte growing with mosses and some epiphytic ferns on tree trunks/branches. It was recorded from Phou Bia Mountain in Saysomboun Province and Phou Chom Voy Mountain in Bolikhamxai Province in Laos, at altitudes of $1023 \mathrm{~m}$ and $2578 \mathrm{~m}$ respectively. Both areas are thickly covered with wet evergreen forests which are frequently misty and have high moisture all year round. Aeschynanthus bracteatus has so far been reported from India, Bhutan, China, Myanmar and northern Vietnam (Middleton, 2009; POWO, 2021). Eighteen species of Aeschynanthus are known from Indochina, among which seven have so far been recorded from Laos (Middleton, 2009; Royal Botanic Garden Edinburgh, continuously updated). Aeschynanthus bracteatus is the eighth species recorded from the country. Aeschynanthus bracteatus differs from A. superbus C.B.Clarke in having the corolla 32-51 mm long (vs corolla $60-85 \mathrm{~mm}$ long in A. superbus) and differs from A. acuminatus Wall. ex A.DC. by the bracts being elliptic or ovate, $15.5-41 \times 4.5-18 \mathrm{~mm}$ (vs bracts ovate or orbicular, $4-10 \times$ 2-10 $\mathrm{mm}$ in A. acuminatus) (Middleton, 2009).

2. Aeschynanthus micranthus C.B.Clarke, Monogr. Phan. 5: 27 (1883); Clarke, F1. Brit. India 4: 340 (1884); Middleton, Edinburgh J. Bot. 66(3): 423 (2009). Trichosporum micranthum (C.B.Clarke) Kuntze, Revis. Gen. P1. 478 (1891). - TYPE: India, Khasia, 19 June 1850, Hooker \& Thomson 879 (lectotype K [K000190170*], designated by Middleton (2009). (Fig. 11B) 


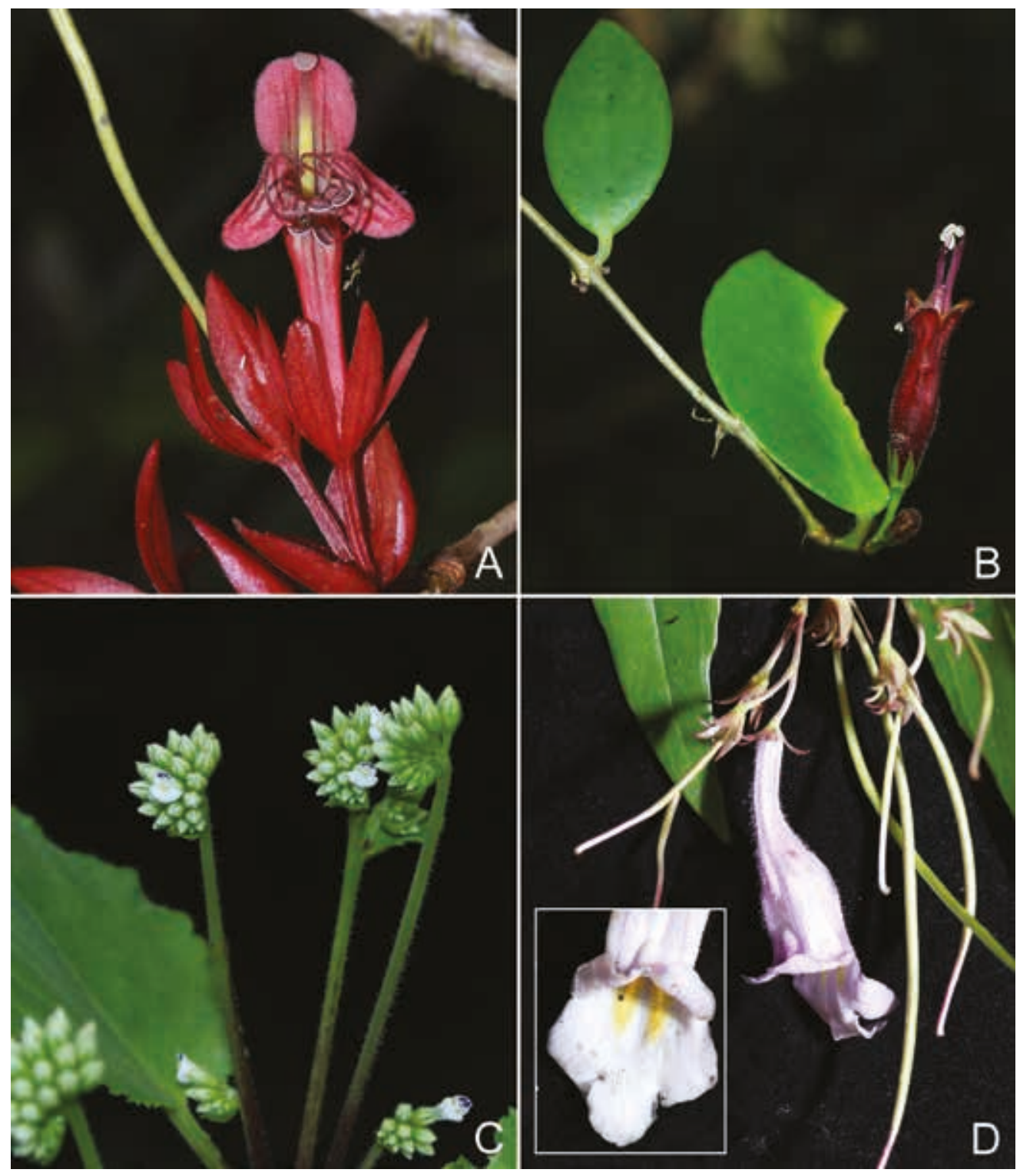

Fig. 11. A. Aeschynanthus bracteatus Wall. ex A.DC., flower front view. B. Aeschynanthus micranthus C.B.Clarke, flower lateral view. C. Epithema ceylanicum Gardner, inflorescence with flowers. D. Lysionotus serratus D.Don., flower lateral view. Inset: Flower front view. A from Lanorsavanh et al. SL 1751; B from Maknoi et al. L3-070; C from Maknoi et al. L3-243; D from Souladeth et al. L3882. (Photos: A, S. Lanorsavanh; B, C, W. Pongamornkul; D, K. Souvannakhoummane)

Specimens examined. LAOS: Louangphabang: Nan District, Pha Yoak Village, Pha Yoak Limestone Forest Reserve Area, 890 m, 19³0'58.5"N 10156'12.3"E, 18 Jul 2014, Maknoi et al. L3-070 (QBG [QBG86066]). 
Notes. This is an epiphytic or lithophytic plant found in deciduous forest in limestone areas at c. $900 \mathrm{~m}$ altitude. It is widely distributed in Asia, but in the revision of the genus Aeschynanthus in Cambodia, Laos and Vietnam (Middleton, 2009) it was recorded only in northern Vietnam. We herein record the occurrence of Aeschynanthus micranthus in Laos.

3. Epithema ceylanicum Gardner, Calcutta J. Nat. Hist. 6: 492 (1846). - Epithema carnosum var. ceylanicum (Gardner) C.B.Clarke in A.DC. \& C.DC., Monogr. Phan. 5(1): 178 (1883). - TYPE: Sri Lanka, Gardner 606 (lectotype K [K000438690*], designated by Bransgrove \& Middleton (2015)). (Fig. 11C)

Specimens examined. LAOS: Louangphabang: Louangphabang District, Lak Sip Village, Phou Souang Forest Reserve Area, 1000 m, 1951'36.2"N 102 ${ }^{\circ} 11^{\prime} 25.0^{\prime \prime} \mathrm{E}, 21 \mathrm{Jul}$ 2014, Maknoi et al. L3-243 (QBG [QBG86239]); Nan District, Pha Youak Village, 14 Aug 2017, Maknoi et al. L9323 (QBG [QBG111375]).

Notes. This is a lithophytic plant found in deciduous forest on limestone at c. $1000 \mathrm{~m}$ altitude in Louangphabang Province in northern Laos. The genus Epithema Blume comprises 20 species (Bransgrove \& Middleton, 2015), among which 19 species are distributed in Asia and one in Africa. In the checklist of vascular plants of Laos (Royal Botanic Garden Edinburgh (continuously updated), two species are listed, Epithema carnosum Benth. and E. saxatile Blume, both widespread in Southeast Asia (Bransgrove \& Middleton, 2015). Epithema ceylanicum had been treated as a variety of E. carnosum but it is easily distinguished from the latter species by the hooked rather than straight hairs on the operculum (Bransgrove \& Middleton, 2015).

4. Lysionotus serratus D.Don, Edinburgh Philos. J. 7(13): 86 (1822); Hooker, Curtis's Bot. Mag. 107: t. 6538 (1881); Clarke, Monogr. Phan. 5: 58(1883); Wang et al., Fl. China 18: 392 (1998); Hilliard \& Burtt, Edinburgh J. Bot. 52: 221 (1995). - Calosacme polycarpa Wall., Numer. List: 804 (1829), nom. nud. - Lysionotus ternifolius Wall., Pl. Asiat. Rar. 2: 20, pl. 118 (1830), nom. illeg. - TYPE: Nepal, 1819, Wallich s.n. (lectotype BM [BM000521822], first step designated by Hilliard \& Burtt (1995), second step designated here). (Fig. 11D)

Hemiboea himalayensis H.Lév., Repert. Spec. Nov. Regni Veg. 9: 329 (1911); Hilliard \& Burtt, Edinburgh J. Bot. 52: 221 (1995). - Lysionotus himalayensis (H.Lév.) W.T.Wang \& Z.Yu.Li, Acta Phytotax. Sin. 30(5): 481 (1992); Hilliard \& Burtt, Edinburgh J. Bot. 52: 221 (1995). - TYPE: Sikkim, Himalaya, Kishap, 28 July 1884, s.coll. s.n. (lectotype G [G00365558], designated by Hilliard \& Burtt (1995); isolectotype $\left.\mathrm{E}\left[\mathrm{E} 00155037^{*}\right]\right)$.

Specimens examined. LAOS: Champasak: Paksong District, near Nong Luang Village on the way to Tad Seua Waterfall, 1260 m, 1504'24.8"N 106²'22.5"E, 17 Sep 2020, Souladeth et al. L3882 (FOF, KAG). 
Notes. This species is an epiphyte with a thick rhizome and succulent stems, so far known from Bhutan, China, India, Japan, Nepal, Myanmar, Thailand and Vietnam (POWO, 2021). We found this species growing on tree branches/trunks near streams in moist evergreen forest on the Bolaven Plateau in Champasak Province, southern Laos. The genus Lysionotus D.Don is native to Asia with 28 species currently accepted (POWO, 2021). The last revision of the species of South Asia and the Indochina Peninsula was published in 1995 (Hilliard \& Burtt, 1995). The genus is widely distributed in Asia, from India eastwards to China and southern Japan (Wang, 1983; Möller et al., 2017), among which only one, Lysionotus levipes (C.B.Clarke) B.L.Burtt, has previously been reported in Laos (Newman et al., 2007). Lysionotus serratus D.Don is distinguished from L. levipes by its succulent and branched stems (vs thin, unbranched), opposite leaves (vs whorled), and glabrous lamina up to $20 \mathrm{~cm}$ long (vs densely puberulent lamina up to $5 \mathrm{~cm} \mathrm{long).}$

5. Microchirita luteola C.Puglisi, Gard. Bull. Singapore 69: 251 (2017). - TYPE: Thailand, Loei, Nong Hin, Suan Sa Wan, Pha Ngam Forest Park, 662 m, 20 November 2017, Tetsana et al. 829 (holotype BKF; isotype SING). (Fig. 12A)

Specimens examined. LAOS: Khammouan: Khoun Kham District, Phou Pha Marn Limestone Forest Viewpoint, $500 \mathrm{~m}, 18^{\circ} 10^{\prime} 43.1^{\prime \prime} \mathrm{N} 104^{\circ} 29^{\prime} 02.3^{\prime \prime} \mathrm{E}, 19$ Oct 2020, Lanorsavanh et al. SL 2003 (HNL, Biology-National University of Laos).

Notes. This species is a herb growing on wet rocks in open areas. In the rainy season, it is commonly found along semi-shaded small streams and roadsides from Phouphaman to Laksao, near the border between the provinces Bolikhamxai and Khammouan. It was described from Thailand (Puglisi \& Middleton, 2017a) and is characterised by its distinctive yellow flowers.

6. Paraboea swinhoei (Hance) B.L.Burtt, Notes Roy. Bot. Gard. Edinburgh 41(3): 439 (1984); Wang et al., Fl. China 18: 364 (1998). - Boea swinhoei Hance, Ann. Sci. Nat., Bot., sér. 5, 5: 231 (1866). - TYPE: Taiwan, 1861, R. Swinhoe 7577 (holotype BM [BM000906714*]). (Fig. 12B)

Specimens examined. LAOS: Louangphabang: Louangphabang District, Lak Sip Village, Phou Souang Forest Reserve Area, 1000 m, 1951'37.6"N 102 ${ }^{\circ} 11^{\prime 2} 27.4^{\prime \prime}$ E, 21 Jul 2014, Maknoi et al. L3-244 (QBG [QBG86240]).

Notes. This species is a shrubby herb with an ascending erect stem up to $1 \mathrm{~m}$ tall. We found this species on humid limestone rocks in seasonal deciduous forest, at $1000 \mathrm{~m}$ altitude. It has been reported in China, Myanmar, Thailand, Vietnam, the Philippines and Taiwan (POWO, 2021). In total, five species of Paraboea, namely P. mahaxayana Z.R.Xu \& B.L.Burtt, P. thorelii (Pellegr.) B.L.Burtt (Xu et al., 2008), P. khotamiae Phonep. \& Souvann. (Phonepaseuth et al., 2021).P. planiflora and P. swinhoei, are 
recorded in the flora of Laos, among which the latter two are recorded in this study. Paraboea multiflora (R.Br.) B.L.Burtt has also been recorded but has now been transferred to the genus Middletonia as M. multiflora (R.Br.) C.Puglisi. Many more species of Paraboea could be expected to be found in Laos with further exploration.

7. Petrocosmea kerrii Craib, Bull. Misc. Inform. Kew 1918: 365 (1918); Wang, Acta Bot. Yunnan. 7: 65 (1985); Wang et al., Fl. China 18: 308 (1998). - Damrongia kerrii (Craib) Pellegr., Fl. Indo-Chine 4: 556 (1930); Wang, Acta Bot. Yunnan. 7: 65 (1985). - TYPE: Thailand, Doi Sutep, 6 September 1914, A.F.G. Kerr 3361 (lectotype K [K000613166*], designated by Wang (1985); isolectotype ABD n.v.). (Fig. 12C)

Petrocosmea wardii W.W.Sm., Notes Roy. Bot. Gard. Edinburgh 13: 175 (1921); Wang, Acta Bot. Yunnan. 7: 65 (1985). - TYPE: China, Yunnan, Nam Ting, 23 April 1921, F. Kingdon Ward 3772 (holotype E [E00061242*]).

Specimens examined. LAOS: Louangphabang: Nan District, 1000 m, 19²9'20.9"N $102^{\circ} 02^{\prime} 43.1^{\prime \prime E}, 28$ Aug 2014, Phoutthavong \& Souvannakhoummane s.n. (alcohol collection in Pha Tad Ke Botanical Garden).

Notes. This is a small herb growing on the exposed cliffs of limestone mountains where scrub tree forest grows. It was described from Thailand by Craib (1918) and is known from Thailand, Myanmar and Yunnan in China (POWO, 2021). In Laos, we found this species in Loungphabang Province in northern Laos, bordering Yunnan. This is first record of this genus in Laos.

8. Pseudochirita guangxiensis (S.Z.Huang) W.T.Wang, Bot. Res. Academia Sinica 1: 22 (1983); Wang et al., Fl. China 18: 293 (1998). - Chirita guangxiensis S.Z.Huang, Acta Bot. Yunnan 2: 102 (1980). - TYPE: China, Guangxi, Zhuang Autonomous Region, 18 August 1979, Huang 7444 (holotype GXMI [GXMI050808]; isotype IBK [IBK00191622*]). (Fig. 12D)

Specimens examined. LAOS: Saysomboun: Anouvong District, 2300 m, 18 $58^{\prime} 22.9^{\prime \prime} \mathrm{N}$ $103^{\circ} 07^{\prime} 36.6^{\prime \prime} \mathrm{E}, 20$ Oct 2020, Lanorsavanh \& Lamxay SL 1753 (HNL, Biology-National University of Laos).

Notes. This species is a lithophytic perennial herb, found growing on rocks along streams in a wet evergreen forest valley at $2300 \mathrm{~m}$ altitude, located near the foothills of Phou Bia Mountain in Saysomboun Province. The flowering season of this species lasts from September to October and fruiting from October to November. The genus Pseudochirita W.T.Wang with two described species is distributed in China and northern Vietnam (Wang, 1983; Wang et al., 1998; POWO, 2021). The original type material was collected in Guangxi, China (Wang, 1983). Our collection material from 


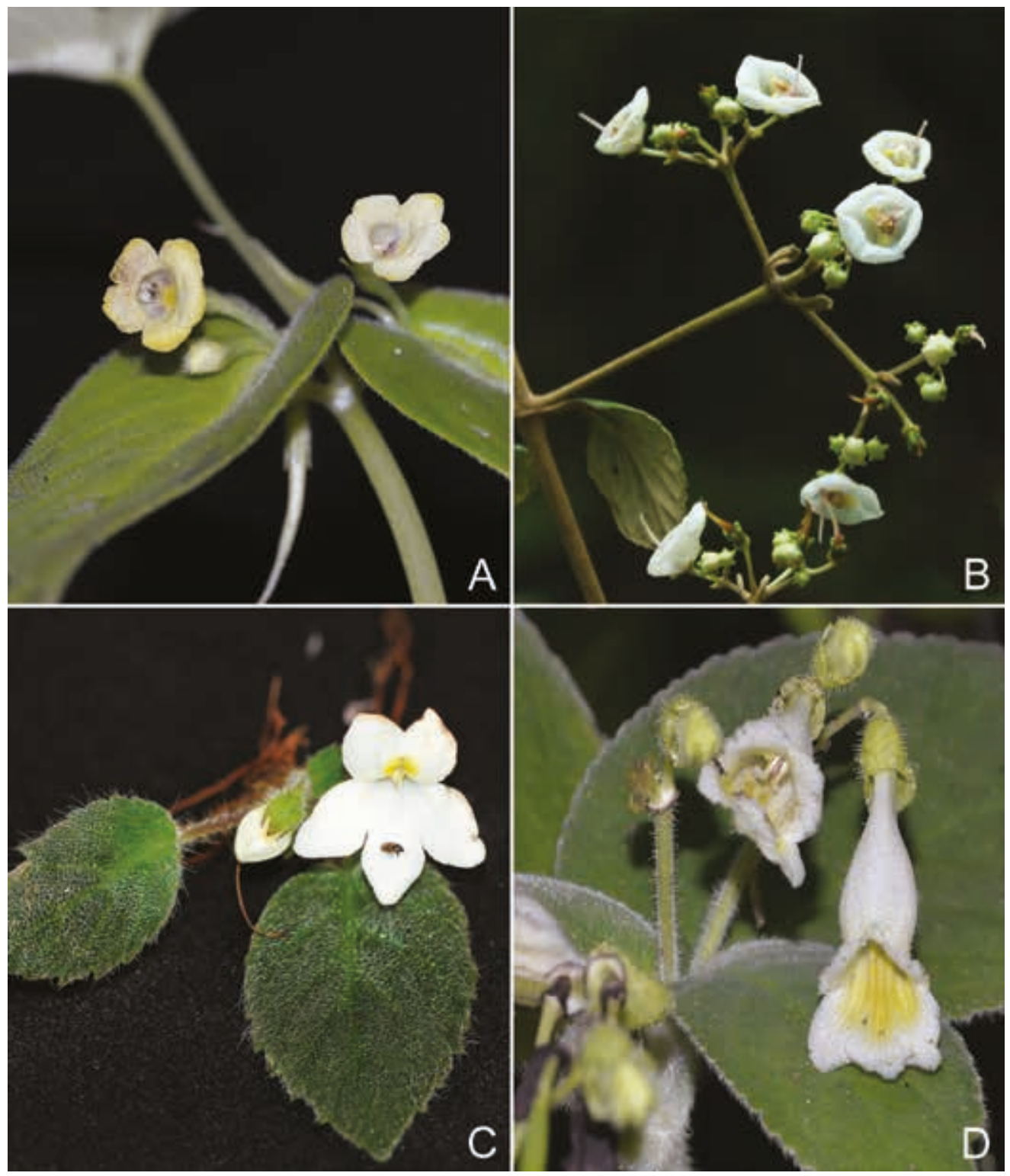

Fig. 12. A. Microchirita luteola C.Puglisi, flowers. B. Paraboea swinhoei (Hance) B.L. Burtt, inflorescence and flowers. C. Petrocosmea kerrii Craib, flower front view. D. Pseudochirita guangxiensis (S.Z.Huang) W.T.Wang, flower front view. A from Lanorsavanh et al. SL 2003; B from Maknoi et al. L3-244; C from Phoutthavong s.n.; D from Lanorsavanh et al. SL 1753. (Photos: A, D, S. Lanorsavanh; B, W. Pongamornkul; C, K. Phoutthavong)

Laos matches well with this species and here we report it as a new record in the flora of Laos. It differs from Pseudochirita trifoliata T.V.Do \& F.Wen from Vietnam in having opposite leaves, calyx campanulate and staminodes three (vs whorls of three, calyx infundibuliform and staminodes two in P. trifoliata) (Do et al., 2021). 
Acknowledgements. We are grateful to David J. Middleton and Michael Möller for constructive and helpful comments on species identification, Charan Maknoi, Peechai Yadee, Khamla Xaiyavong, Khan Yuangyayear and Thyraphon Vongthavone for assistance during field work, and Kitthisak Phoutthavong for providing photos. We also would like to thank the curators and staff of the following herbaria: FOF, HNL, KAG, QBG and Pha Tad Ke Botanical Garden for their kind permission to study the specimens in their care. The field work and our study were supported by the Nagao Natural Environment Foundation of Japan, the Environment Protection Fund (EPF) under the project 'Capacity Enhancement of Lao's Natural Sciences', Sub-Project Number PICE-LENS2-010 and KHAMPHAY SANA Group.

\section{References}

Averyanov, L.A., Xu, W.B., Nguyen, K.S. \& Maisak, T.V. (2020). Paraboea villosa (Gesneriaceae), a new species from Northern Vietnam. Taiwania 65(1): 33-36.

Bransgrove, K. \& Middleton, D.J. (2015). A revision of Epithema (Gesneriaceae). Gard. Bull. Singapore 67: 159-229.

Craib, W.G. (1918). XXXV. Contributions to the flora of Siam. Bull. Misc. Inform. Kew 1918: 362-371.

Do, T.V., Hoang, M.T., Xin, Z.-B., Wei, Y.-G., Meng, D.-C. \& Wen, F. (2021). Pseudochirita trifoliata (Gesneriaceae), a new species from karst limestone in northern Vietnam. Phytotaxa 489(2): 182-190.

Hilliard, O. \& Burtt, B.L. (1995). Old World Gesneriaceae. IV. Notes on Didymocarpus and Lysionotus. Edinburgh J. Bot. 52: 215-224.

IUCN Standards and Petitions Committee (2019). Guidelines for Using the IUCN Red List Categories and Criteria. Version 14. Prepared by the Standards and Petitions Committee. Available from http://iucnredlist.org/documents/RedListGuidelines.pdf.

Kaitongsuk, S., Triboun, P., Suddee, S., Ue-Aree, P. \& Sungkaew, S. (2021). Paraboea khaoyaica (Gesneriaceae), a new species from Thailand. Gard. Bull. Singapore 73: 203-207.

Middleton, D.J. (2007). A new species and a new combination in Aeschynanthus (Gesneriaceae) from Laos. Edinburgh J. Bot. 64(1): 45-50.

Middleton, D.J. (2009). A revision of Aeschynanthus (Gesneriaceae) in Cambodia, Laos and Vietnam. Edinburgh J. Bot. 66: 391-446.

Middleton, D.J. (2018). Two new species of Paraboea (Gesneriaceae) from Vietnam. Edinburgh J. Bot. 75: 421-425.

Middleton, D.J., Nishii, K., Puglisi, C., Forrest, L.L. \& Möller, M. (2015). Chayamaritia (Gesneriaceae: Didymocarpoideae), a new genus from Southeast Asia. Pl. Syst. Evol. 301: 1947-1966.

Middleton, D.J., Armstrong, K., Baba, Y., Balslev, H., Chayamarit, K., Chung, R.C.K., Conn, B.J., Fernando, E.S., Fujikawa, K., Kiew, R. et al. (2019). Progress on Southeast Asia's flora projects. Gard. Bull. Singapore 71: 267-319.

Möller, M., Nampy, S., Janeesha, A.P. \& Weber, A. (2017). The Gesneriaceae of India: consequences of updated generic concepts and new family classification. Rheedea 27 : $23-41$.

Nangngam, P. \& Maxwell, J.F. (2013). Didymocarpus (Gesneriaceae) in Thailand. Gard. Bull. Singapore 65: 185-225. 
Nangngam, P. \& Middleton, D.J. (2014). Five new species of Didymocarpus (Gesneriaceae) from Thailand. Thai Forest Bull., Bot. 42: 35-42.

Newman, M.F., Ketphanh, S., Svengsuksa, B., Thomas, P., Sengdala, K., Lamxay, V. \& Armstrong, K. (2007). A Checklist of the Vascular Plants of Lao PDR. Edinburgh: Royal Botanic Garden Edinburgh.

Nguyen, C.H., Averyanov, L.V. \& Wen, F. (2019). Hemiboea thanhhoensis (Gesneriaceae), a new species from northern Vietnam. Phytotaxa 414(3): 146-150.

Panyadee, P., Tanming, W. \& Maknoi, C. (2020). Plants without borders: new records of two presumed Thai endemic Gesneriaceae in Laos. Gard. Bull. Singapore 72: 285-290.

Phonepaseuth, P., Souvannakhoummane, K., Tagane, S., Souladeth, P., \& Yahara, T. (2021). A new species of Paraboea and a new species record of Middletonia (Gesneriaceae) from a limestone karst of Central Laos. Thai For. Bull., Bot. 49: 135-141.

Phuong, V.X., Vu, D.Q. \& Xuyen, D.T. (2014). Genus Didymocarpus Wall. and a new record of species Didymocarpus purpureobracteatus Smith for the flora of Vietnam from Xuan Lien National Reserve. Tap Chi Sinh Hoc 36(1): 46-50.

POWO (2021). Plants of the World Online. Facilitated by the Royal Botanic Gardens, Kew. http://plantsoftheworldonline.org/. Accessed 9 Sep. 2020.

Prasanna, N.S. \& Gowda, V. (2020). Rediscovery of four narrow endemic Didymocarpus species (Gesneriaceae) from Mizoram, India, with revised species descriptions and lectotypifications. PhytoKeys 148: 1-19.

Prasanna, N.S., Liu, D.T, Saryan, P. Duan, S.Z., Cai, L. \& Gowda, V. (2020). Didymocarpus sinoindicus (Gesneriaceae), a new species from India and China. Rheedea 30(1): 135142.

Puglisi, C. \& Middleton, D.J. (2017a). A revision of Microchirita (Gesneriaceae) in Thailand. Gard. Bull. Singapore 69: 211-284.

Puglisi, C. \& Middleton, D.J. (2017b). A revision of Middletonia (Gesneriaceae) in Thailand. Thai For. Bull., Bot. 45: 35-41.

Puglisi, C., Suddee, S., Triboun, P. \& Middleton, D.J. (2015). A new species of Paraboea (Gesneriaceae) from Thailand. Gard. Bull. Singapore 67: 101-106.

Puglisi, C., Yao, T.L., Milne, R., Möller, M. \& Middleton, D.J. (2016). Generic recircumscription in the Loxocarpinae (Gesneriaceae), as inferred by phylogenetic and morphological data. Taxon 65: 277-292.

Royal Botanic Garden Edinburgh (continuously updated). A checklist of the vascular plants of Lao PDR. http://padme.rbge.org.uk/laos/. Accessed 1 May 2021.

Souvannakhoummane, K. \& Phonepaseuth, P. (2020). Didymocarpus albiflorus (Gesneriaceae), a new species from Vientiane capital, Lao PDR. Taiwania 65(2): 109-113.

Souvannakhoummane, K., Souladeth, P., Tagane, S., Yang, C.J. \& Yahara, T. (2019). Flora of Nam Kading National Protected Area VI: Didymocarpus middletonii (Gesneriaceae), a new species from limestone. Edinburgh J. Bot. 76(1): 45-54.

Tran, T.L., Ly, N.S., Tran, M.N., Nguyen, X.T., Cao, N.G \& Pham, H.D. (2020). Didymocarpus phuquocensis, a new species of Gesneriaceae from Phu Quoc Island, South-western Vietnam. PhytoKeys 159: 35-44.

Triboun, P. (2013). Paraboea middletonii (Gesneriaceae), a new species from Thailand. Thai For. Bull., Bot. 41: 45-47.

Triboun, P. \& Middleton, D.J. (2012). Twenty new species of Paraboea (Gesneriaceae) from Thailand. Gard. Bull. Singapore 64: 333-370.

Wang, W.T. (1983). Revision of Lysionotus in China. Guihaia 3: 249-284. 
Wang, W.T., Pan, K.Y. \& Li, Z.Y. (1998). Gesneriaceae. In: Wu, Z.Y. \& Raven, P.H. (eds) Flora of China, vol. 18, pp. 244-401. Beijing: Science Press; and St. Louis: Missouri Botanical Garden Press.

Weber, A., Middleton, D.J., Clark, J.L. \& Möller, M. (2020). Keys to the infrafamilial taxa and genera of Gesneriaceae. Rheedea 30(1): 5-47.

Wen, F., Tang, W.-X. \& Wei, Y.-G. (2011). Hemiboea angustifolia (Gesneriaceae), a new species endemic to a tropical limestone area of Guangxi, China. Phytotaxa 30: 53-59.

Xu, Z.R. \& Burtt, B.L. (1991). Towards a revision of Paraboea (Gesneriaceae): I. Edinburgh J. Bot. 48(1): 1-18.

Xu, Z.R., Burtt, B.L., Skog, L.E. \& Middleton, D.J. (2008). A revision of Paraboea (Gesneriaceae). Edinburgh J. Bot. 65(2): 161-347.

Zhang, C.F., Tian, J., Peng, S., Wang, J.J., Wang, Y., Hu, G.W. \& Wang, Q.F. (2020). Didymocarpus longicalyx (Gesneriaceae), a new species from southwestern Yunnan, China. Phytotaxa 475(1): 59-66. 